\title{
Geological Heritage at Risk in NW Spain. Quaternary Deposits and Landforms of "Southern Coast" (Baiona-A Garda)
}

\author{
Manuela Costa-Casais • M. Isabel Caetano Alves
}

Received: 16 February 2012 / Accepted: 27 March 2013 / Published online: 8 May 2013

(C) The European Association for Conservation of the Geological Heritage 2013

\begin{abstract}
Over the last decade, a knowledge base has been built up worldwide in relation to geological heritage and geodiversity, and respective working methodologies. However, the absence of knowledge and technical information by the local, regional and national authorities about geosites makes it difficult to create appropriate legislation and to assure a good management. There is also a public ignorance about geological processes and their relationship to biodiversity, as well as their value as natural heritage. This study focuses on the Autonomous Community of Galicia (NW Spain), specifically the "Southern Coast" area established in the Planning Programme for the Coast (POL) and brings to light the importance of the Quaternary deposits and associated landforms. The study concludes that the Southern Coast should be recognized as an area-type geosite. Taking into account the evaluation of their scientific value, the landforms of Oia and San Xián are proposed as geosites. Legal mechanisms of protection need to be reinforced and new, more specific ones, developed in tandem that make reference to the fact that these landforms exemplify environmental records of the past. This area is unique on a national level due to the scientific and educational value of the deposits. Therefore, they should be
\end{abstract}

M. Costa-Casais $(\bowtie)$

Institute of Heritage Sciences (Incipit), Spanish National

Research Council (CSIC), San Roque,

2. 15704 Santiago de Compostela,

A Coruña, España

e-mail: manuela.costa-casais@incipit.csic.es

M. I. Caetano Alves

Geology Centre of the University of Porto and Earth Sciences

Centre of the University of Minho, Campus de Gualtar,

4710-057 Braga, Portugal

e-mail: icaetano@dct.uminho.pt proposed to the Spanish Geological Survey (IGME) for inclusion in the general list of geosites of the Spanish State.

Keywords Geoconservation · Geosites · Geological heritage · Pleistocene-Holocene · Coast deposits . Galicia-NW Spain

\section{Introduction}

Over the last decade, a knowledge base, along with the legislation that this implicitly requires, has been built up worldwide in relation to the characterisation, conservation and management of both geological heritage and geodiversity. In 2007, for the first time in Spain, several important laws were passed by the Spanish Parliament explicitly mentioning geological heritage and geodiversity. Law 5/2007 (National Parks Network) incorporates a list of geological contexts that are most representative of Spanish geodiversity. Law 42/2007 (Natural Heritage and Biodiversity) elaborates on the conservation and management of geological heritage and geodiversity and incorporates the list of geological frameworks as identified for Spain under the UNESCO-IUGS Global Geosites Project. The law includes the concepts of geodiversity and geological heritage and prescribes geoconservation as one of the main bases for nature management and conservation in Spain. Law 45/2007 (Sustainable Development of Rural Environment) establishes that rural development plans must consider the conservation and sustainable use of archaeo-industrial and geological heritage. Law 42/2007 identifies the public administrations of Spain's autonomous regions (communities) as entities responsible for the preservation of natural heritage and hints that geoheritage must be inventoried by geosites. Thus, the Spanish Geological Survey (IGME) has launched a 
project to inventory National Geosites in Spain. It was carried out collaboratively between Spanish research institutes and scientific societies related to Earth Sciences. This inventory of geosites is not a closed list, and therefore, new proposals can be suggested. The new legislative framework on nature conservation implies that inventories and studies of the state of conservation of geodiversity and geological heritage should be carried out. The methodological steps required to advance the characterisation and protection of geological heritage have already been defined (García-Cortés and Carcavilla 2009). However, in many cases, the lack of scientific knowledge and information held by the Administration regarding national, regional and local "Geosites" makes the creation of appropriate regulations difficult: What has not been identified cannot be protected.

This study concentrates on the Autonomous Community of Galicia, more specifically, in the coastal area established in the Plan de Ordenación del Litoral de Galicia (POL) Xunta de Galicia (2010) - the Planning Programme for Coastal areas of Galicia, as the "Southern Coast"- and aims to bring to light the relevance of ancient sedimentary deposits located along this stretch of coast. In general, coastal modelling is controlled by a series of factors of diverse origin. The formation and evolution of the coastal relief is produced by means of the interface between ocean, continent and atmosphere, thereby creating an interaction between marine, continental and sub-aerial processes. The processes that act on the coastal environment are more diverse than those which prevail on the continent, thus imposing particular characteristics on the coast and thereby producing geodiversity (Nieto 2001; Cairnes 2003; Commonwealth of Australia 2004; Gray 2004; Kozlowski 2004; Rojas 2005; Law 42/2007; Carcavilla et al. 2008, 2011; Browne 2010; Hansom and Rennie 2010). Serrano and Ruíz-Flaño (2007) applied a system to study the concept of geodiversity which includes all components of the physical environment, based on "the variability of abiotic nature, including lithological, tectonic, geomorphological, pedological, hydrological and topographical elements as well as physical processes on the surface of the Earth, the seas and oceans, along with systems generated by natural, endogenous, exogenous and anthropic processes, which comprise the diversity of particles, elements and places" that can be applied to this stretch of coast.

The pervasive lack of awareness in today's society regarding geological processes and their effects on the landscape is of such magnitude that their relationship to biodiversity and their value as part of the natural heritage is almost completely ignored (Guillén-Mondéjar and Del Ramo 2004; Guillén-Mondéjar 2007). Within this context, the objective of the POL (Decree Law 20/2011, passed on 23 February 2011) of the Autonomous Community of Galicia is, in accordance with what is established in the Law 6/2007, to take urgent steps regarding the planning of the territory and the coastal areas in particular (24 May 2007) "to establish the principles and general rules for a territorial planning strategy of the coastal area based on criteria of durability and sustainability, in addition to establish the necessary regulations in order to guarantee the conservation, protection and assessment of the coastal regions. Among its functions is that of highlighting those coastal ecosystems and geomorphological and scenic sites which, due to their natural, current or potential characteristics, deserve conservation and protection". The territorial model foreseen by the POL divides the area it encompasses into continuous and discontinuous sectors. Among the former, the area of coastal protection can be highlighted. This area encompasses zones which possess great natural and environmental, as well as scenic, value. To be more precise, these areas are rocky landforms (cliffs, islands and islets) and beach-dune systems along with associated coastal vegetation formations and areas affected by coastal dynamics. A highly detailed cartography is associated with the POL. The ancient sedimentary deposits located along the coast are not specifically mentioned, or referred to, in its many pages. It is not clear whether they are considered to be cliffs, which would mean that they are likened to rocky formations (which is not correct); or perhaps they are not included in any category of the named coastal formations, which would imply that they are not protected. The lack of awareness of these deposits, or the mere fact that they have either been omitted, or included as other coastal formations, makes their recognition and promotion unfeasible. The term "areas of great natural and environmental value" is used in the POL to refer to the protection of the coast. Therefore, it could be understood that the deposits are included in this catch-all term, although nowhere are they identified as either deposits or specific formations with their own importance. This absence of a categorisation or definition implies a lack of knowledge and reflects a significant scientific gap regarding the value of these formations in helping us to understand the evolution of the Galician coast, and more specifically that of the Southern Coast.

At present, the deposits act as cliffs. Unlike rocky cliffs, however, they are made up of unconsolidated sedimentary material, which is more susceptible to erosion. In the documentation of the POL, reference is made to the sedimentary deposits as: Quaternary deposits; Quaternary deposits made up of colluvial deposits and marine terraces; Quaternary material of colluvial origin which extends parallel to the coast without coming into contact with the sea; and colluvial deposits in contact with debris fans associated to fluvial channels and layers of marine terraces. A large variety of names is given to the deposits, creating confusion when it comes to interpreting their formation. With such a range of terms, it seems that different formations are being referred to that are discontinuous in space. It is essential that these 
deposits are recognised by the administrations and by society in general, because they are archives of the environmental changes that have occurred since the Late Pleistocene. For this reason, they are of great scientific and educational value and must be protected and preserved, for as long as natural processes allow.

A review of the literature on the sedimentary deposits of the Galician coast shows that there is a significant number of scientific publications that can be organized into six groups: (a) studies on the classification of ancient sedimentary deposits and their relation with morphogenetical processes
(Costa-Casais et al. 1996a; Pérez et al. 1999); (b) physicochemical characterisations of the deposits (Costa-Casais et al. 1996a; Martínez-Cortizas et al. 1996, 1997; Martínez-Cortizas and Costa-Casais 1997; (c) studies on colluvial deposits of nival origin (Costa-Casais et al. 2002, 2005; Pérez et al. 1998); (d) the retreat of sedimentary cliffs (Blanco-Chao et al. 2009); (e) palaeoenvironmental interpretation and reconstruction (Cano et al. 1997; Threnhaile et al. 1999; Costa-Casais 2001; Blanco-Chao et al. 2002, 2003; Costa-Casais 2002; (f) relationship to Pleistocene climate, as in Heinrich events (Costa-Casais et al. 2007a, b, 2008).
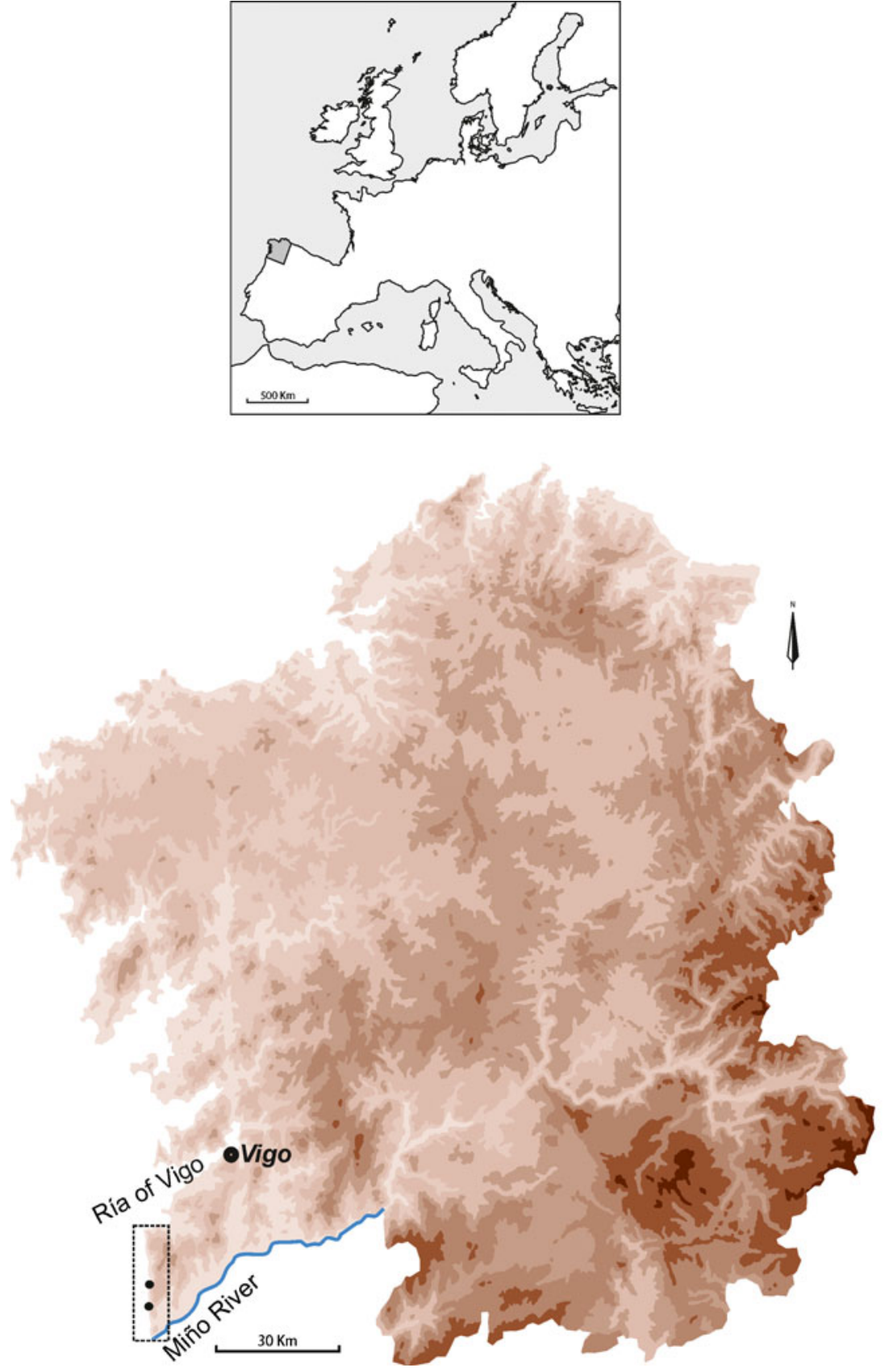

Fig. 1 Location of the study area and selected geosites

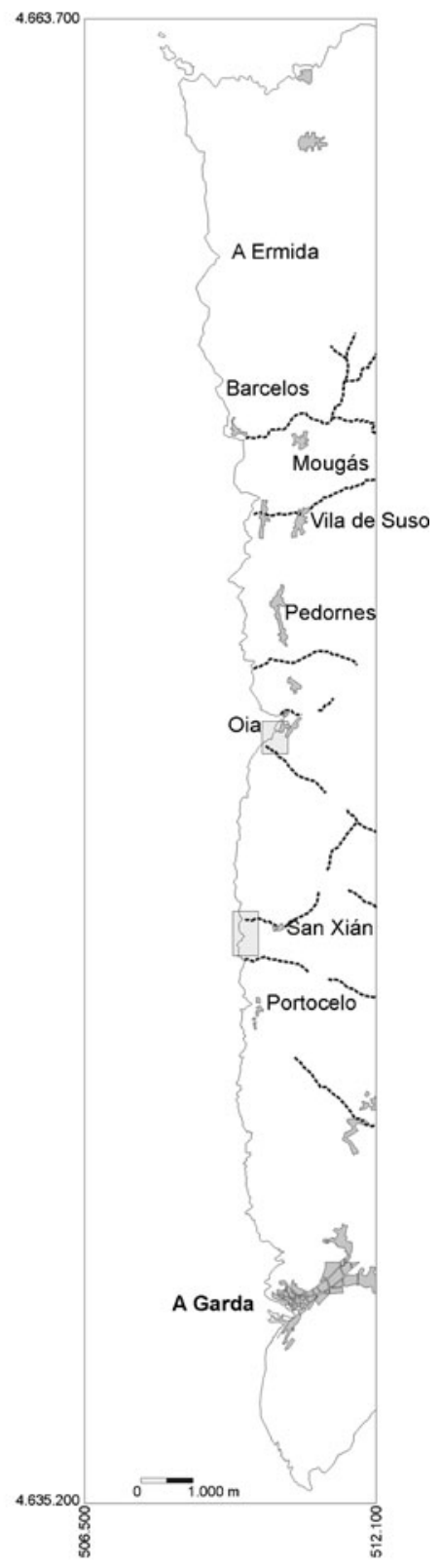


Taking into account these previous works and considering the current administrative context, the aim of this study is to demonstrate the importance and interest of the ancient sedimentary deposits located on the Galician coast, as both landforms and palaeoenvironmental archives. It is expected that this sector of the Southern Coast of Galicia will be recognised as an area of geological importance, supported by 47 potential geosites of differing values and degrees of relevance. In particular, as a result of an evaluation of the scientific value, two sites will be proposed as geosites, Oia and San Xián, in order to promote their geoconservation (Brilha 2005; Carcavilla et al. 2007; Henriques et al. 2011).

\section{Materials and Methods}

\section{Regional Setting}

The study area is located between the Ria of Vigo and the mouth of the Miño River, in the NW of the Iberian Peninsula, defined in the POL as the Southern Coast (Fig. 1). This is a rare sector of coast due to the fact that it has a straight planform, in a coast otherwise characterised by an irregular aspect. The lithology is extremely homogeneous, composed of two mica granites, with a large number of quartz and pegmatite dykes. The joint pattern is very dense, with a mean distance between fractures of 30$40 \mathrm{~cm}$, with directions NE-SW and NW-SE and dipping between $20^{\circ}$ and $90^{\circ}$ (Blanco-Chao et al. 2006).
The tidal environment is semidiurnal with a mean tidal range of $2.5 \mathrm{~m}$ and a spring tidal range between 3.75 and $4 \mathrm{~m}$ (Puertos del Estado, Vigo tidal station). The tidal range commonly exceeds $4 \mathrm{~m}$ due to pressure and wind surge. Given the straight planform, the coast is largely exposed to waves coming mainly from the NW, followed by N, W and SW directions. The Atlantic coast of Galicia has a high wave energy environment with marked seasonal behaviour. The highest waves usually occur in autumn and winter with a mean significant height $\left(\mathrm{H}_{1 / 3}\right)$ of $2.34 \mathrm{~m}$ and a maximum of $8.95 \mathrm{~m}$ and have a mean period of 7-8 s, with less than $9 \%$ of the waves having mean periods of more than $10 \mathrm{~s}$. During the summer, the mean $\mathrm{H}_{1 / 3}$ is $1.3 \mathrm{~m}$ with a maximum of $6.62 \mathrm{~m}$ and a mean period of $6 \mathrm{~s}$, with less than $1 \%$ of the waves exceeding a period of $10 \mathrm{~s}$. The maximum wave height recorded is $14 \mathrm{~m}$ (Puertos del Estado, Cabo Silleiro REMRO Buoy 1991-2005). The dominant wind regime has the highest frequencies in directions $\mathrm{N}, \mathrm{NNE}$ and NNW, followed by wind directions SW and W, while the wind regime from the E, SE, S and SW is very infrequent.

The sector is characterised by the presence of coastal mountains reaching elevations of up to $600 \mathrm{~m}$, with seaward slopes dissected by fracture-controlled valleys running $\mathrm{E}$ to $\mathrm{W}$ and NE to SW. The valleys usually terminate in small embayments at the coast. The mountains constitute orographic barriers which provided suitable conditions for fluvio-nival and periglacial slope processes when the sea level was lower than today in the isotopic stages 3 and 2 (Costa-Casais 2001). These deposits were

LEGEND
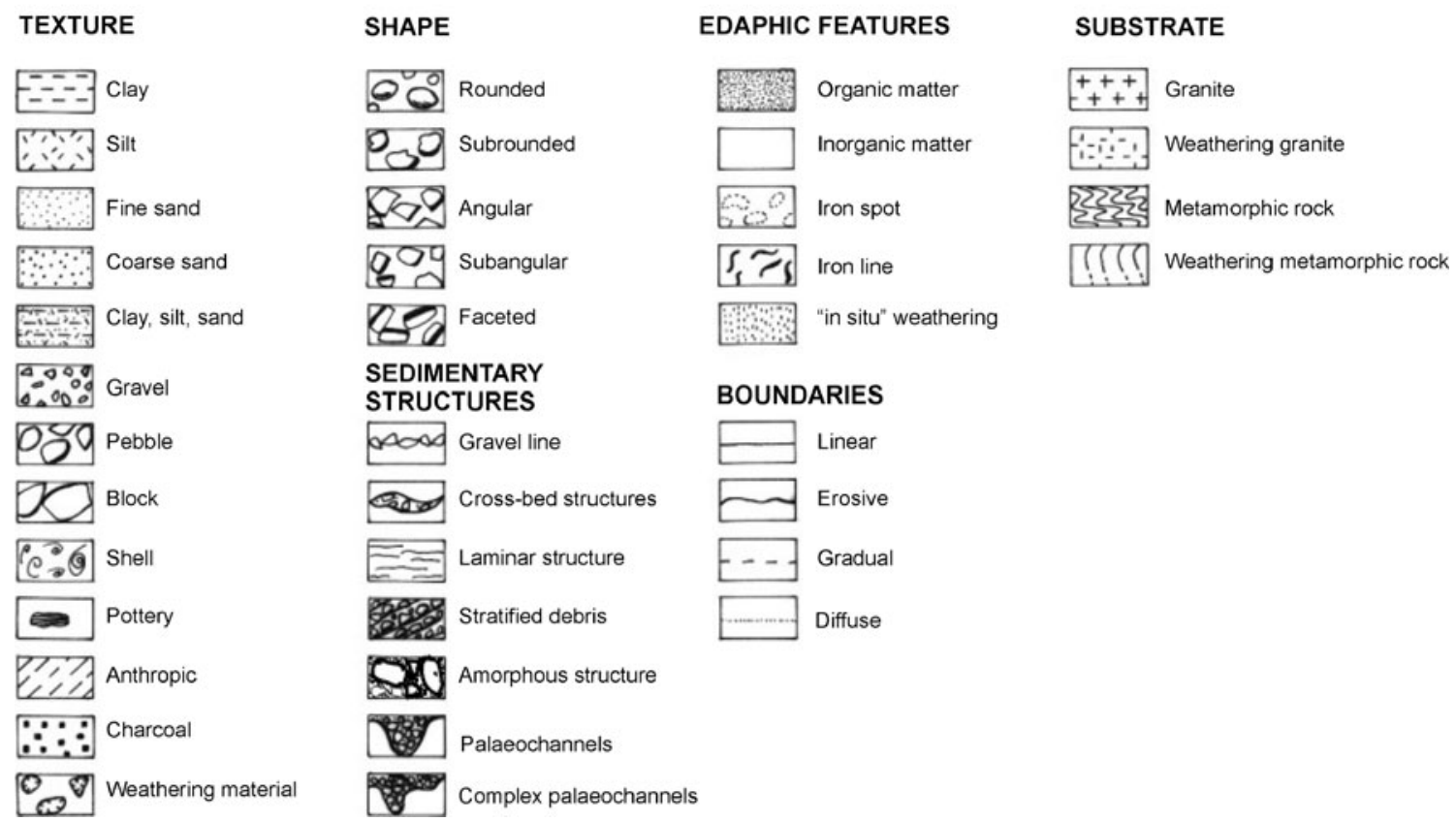

Fig. 2 Legend of sedimentological and stratigraphical features for the selected deposits 
subsequently covered by Holocene sediments and cut into sea cliffs during the post-glacial transgression. The coast was covered in places by fluvio-nival and periglacial slope deposits, which were eroded and cut back during the Holocene transgression (Blanco-Chao et al. 2002, 2003), exposing the underlying Late Interglacial (isotopic stage $5 \mathrm{e}$ ) shore platforms.

Fieldwork and Sampling

Topographical maps at 1:10,000 scale, aerial photos (flight 1981-1983) at 1:18,000 scale and colour photos (flight 1989) at 1:5,000 scale were used in order to identify the landforms and carry out the geomorphological characterisation of the sector. This phase consisted of three stages: (a) differentiating the relief units and coastal forms, (b) locating and describing ancient sedimentary deposits and relating them to the other coastal forms and (c) describing representative facies in selected deposits. The most interesting features from the geomorphological and pedosedimentary points of view were selected for sampling in order to characterise the depth-variations of their physicochemical properties. In carrying out the sedimentological descriptions, the following properties were taken into account: texture, structure, disposition of the material, granoclassification, morphology of the fragments and inclination (Francou and Hétu 1989). Representative sedimentary outlines of the selected sequences were made. A legend was also designed synthesising the most important pedo-sedimentary characteristics. It was divided into the following sections: grain-size/texture, shape of the material, sedimentary structures, pedofeatures, type of substrate/rock and type of contact between sedimentary layers (Fig. 2).

Table 1 Radiocarbon dating and calibrated ages $(2 \sigma)$ for the sector of the South Coast

\begin{tabular}{|c|c|c|c|c|c|}
\hline Sample & Site & Dating material & ${ }^{14} \mathrm{C}$ year BP & $2 \sigma$ cal year BP & Source \\
\hline GrN-20828 & Mougás & Organic soil & $5,530 \pm 60$ & $6,263-6,442$ & Costa-Casais et al. $1996 \mathrm{~b}$ \\
\hline GrN-20829 & Mougás & Organic soil & $13,720 \pm 110$ & $16,590-17,102$ & Costa-Casais et al. $1996 \mathrm{~b}$ \\
\hline GrN-20511 & Mougás & Organic silt and clay & $14,100 \pm 200$ & $16,795-17,702$ & Costa-Casais et al. $1996 \mathrm{~b}$ \\
\hline No reference & Mougás & Not described & 13,600 & $16,593-16,932$ & Nonn 1966 \\
\hline No reference & Mougás & Peat & $18,200 \pm 900$ & - & Nonn 1966 \\
\hline No reference & Mougás & Charcoal & $7,340 \pm 330$ & $7,574-8,808$ & Franz 1967 \\
\hline $\mathrm{I}-2177$ & Mougás & Charcoal & $>39,900$ & - & Butzer 1967 \\
\hline GrN-8324 & Mougás & Peat & $18,030 \pm 160$ & - & Brosche 1982 \\
\hline GrN-8324 & Mougás & Charcoal & $9,800 \pm 70$ & $11,084-11,394$ & Saa 1986 \\
\hline BETA93270 & Mougás-I & Paleosoil: sand, silt, clay & $13,790 \pm 90$ & $16,703-17,126$ & Cano et al. 1997 \\
\hline Ua33776 & Oia- $0-8$ & Organic silt and clay & $1,860 \pm 30$ & $1,720-1,870$ & Blanco et al. in progress \\
\hline Ua33777 & Oia-I-20 & Organic silt and clay & $25,440 \pm 415$ & - & Blanco et al. in progress \\
\hline Ua33778 & Oia-I-53 & Organic silt and clay & $24,885 \pm 385$ & - & This paper \\
\hline Ua33779 & Oia-I-56 & Organic silt and clay & $26,675 \pm 480$ & - & This paper \\
\hline Ua33781 & Oia-II-30 & Organic silt and clay & $28,670 \pm 620$ & - & This paper \\
\hline Ua33780 & Oia-II-56 & Organic silt and clay & $35,650 \pm 1,475$ & - & Blanco et al. in progress \\
\hline BETA93267 & Oia Sur-I & Paleosoil: silt, clay & $32,980 \pm 530$ & - & Cano et al. 1997 \\
\hline BETA93271 & Canela I-VII & Paleosoil: silt, clay & $3,410 \pm 60$ & $3,554-3,832$ & Cano et al. 1997 \\
\hline BETA95397 & Canela II-III & Paleosoil: silt & $4,760 \pm 80$ & $5,315-5,612$ & Cano et al. 1997 \\
\hline BETA95396 & Canela II-IV & Paleosoil: silt & $4,030 \pm 80$ & $4,338-4,729$ & Cano et al. 1997 \\
\hline BETA95395 & Canela II-V & Paleosoil: silt & $3,330 \pm 70$ & $3,396-3,720$ & Cano et al. 1997 \\
\hline $\mathrm{I}-2261$ & San Xián & Charcoal & $28,400+1,200-1,000$ & - & Butzer 1967 \\
\hline BETA93268 & San Xián I-I & Paleosoil: sand, silt, clay & $28,000 \pm 230$ & - & Cano et al. 1997 \\
\hline BETA93269 & San Xián IV-I & Paleosoil: sand, silt, clay & $38,830 \pm 2,200$ & - & Cano et al. 1997 \\
\hline $\mathrm{I}-2176$ & Fedorento & Organic detritus & $18,700 \pm 320$ & - & Butzer 1967 \\
\hline Gr-N-8320 & Fedorento & No described & $28,000 \pm 450$ & - & Brosche 1983 \\
\hline GrN-8321 & Fedorento & No described & $41,500+2,200-1,700$ & - & Brosche 1982 \\
\hline GrN-8322 & Fedorento & No described & $43,500+2,000-1,600$ & - & Brosche 1982 \\
\hline BETA95398 & Area Grande X & Paleosoil: sand, silt, clay & $32,260 \pm 360$ & - & Cano et al. 1997 \\
\hline GrN-8323 & A Guarda & Charcoal & $26,450 \pm 230$ & - & Brosche 1982 \\
\hline
\end{tabular}


Four complex sedimentary sequences located in Oia and another one in Mougás were sampled. The maximum depth of the sequences in Oia is $725 \mathrm{~cm}$. Continuous samples, $5 \mathrm{~cm}$ in thickness, were collected in most of the deposits, except in layers dominated by coarse material. The total number of samples collected in Oia was 154 ( 8 in the profile Oia- 0,56 in Oia-I, 56 in Oia-II and 34 in Oia-III). The maximum depth in Mougás is $236 \mathrm{~cm}$, and continuous samples, $5 \mathrm{~cm}$ in thickness, were also collected, since the fine material dominates in this deposit. The samples were wrapped in plastic bags and taken to the laboratory for analysis. The description of the colluvium was made according to Food and Agriculture Organization (FAO) guidelines for soil description (FAO 2006); and the colour of dry soil samples was determined according to the Munsell Soil Colour Chart (1990). The samples were air-dried and sieved to separate the fine earth $(<2 \mathrm{~mm})$ from gravel and coarser particles. Analytical determinations were performed in the fine earth fraction; for some analyses (such as the chemical composition), the samples were milled to very fine powder and homogenised.

Sample Preparation: Physical and Chemical Analyses of the Sediments

The sample characterisation included physical properties (loss on ignition, particle size, gravel content and morphometry as well as degree of weathering, colour, structure and consistency and quantification of macrocharcoal particles) and geochemical properties (soil reaction- $\mathrm{pH}$, geochemical composition).

\section{Radiocarbon Age Dating}

Samples for radiocarbon dating were selected according to: (a) changes in total carbon content in the deposit, which could be indicative of the presence of buried soil cycles; (b) location in the sequence and relationship with erosive discontinuities; (c) base of the colluvium, to determine the time of the beginning of accumulation or the time when the former soil was truncated.

For those dates found in older literature references, the methodology used for sample preparation before radiocarbon analysis is not known. In our research group, the preparation protocol for soil samples (fine earth fraction $<2 \mathrm{~mm}$ ) is as follows: Samples are shaken in ultrapure distilled water for $16 \mathrm{~h}$, and then the suspension is filtered through a sieve of $50 \mu \mathrm{m}$ mesh-size, thereby removing sand, roots and some fresh organic remains. Radiocarbon age determinations were performed on "humic acids" obtained by the standard acid-alkaline-acid isolation. Accelerator mass spectrometry was performed at the

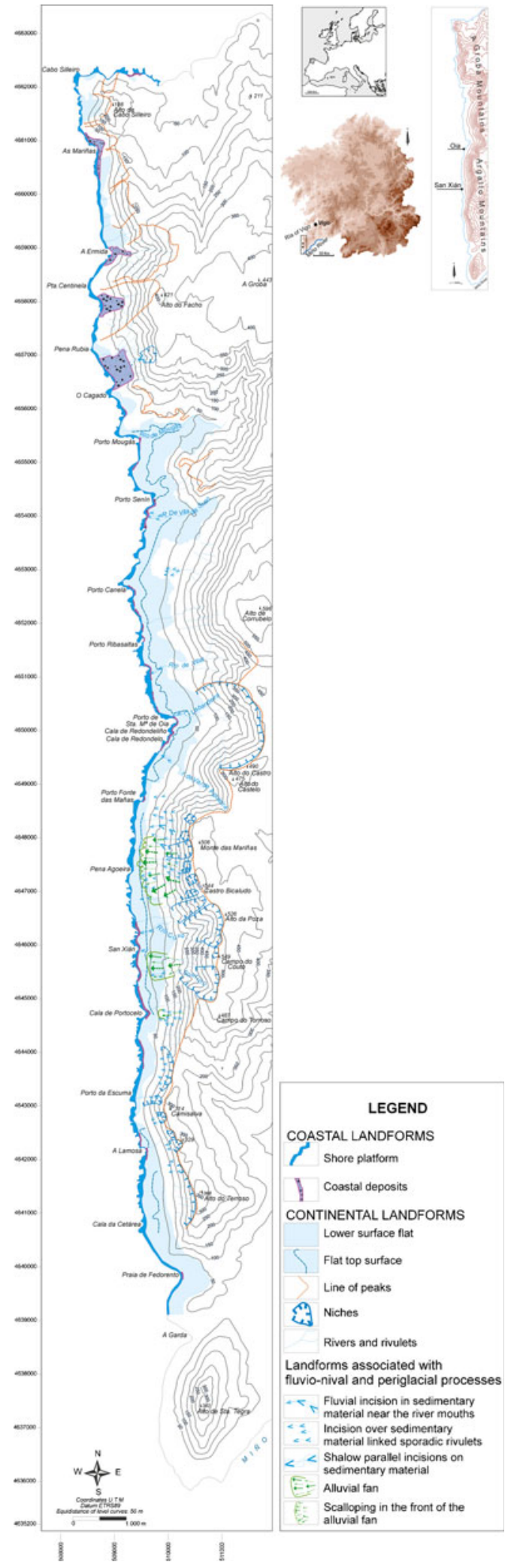

Fig. 3 Geomorphological map of the study area and location of ancient sedimentary deposits 
Table 2 Evaluation of scientific, educational and touristic values of the Oia Sur and San Xián geosites

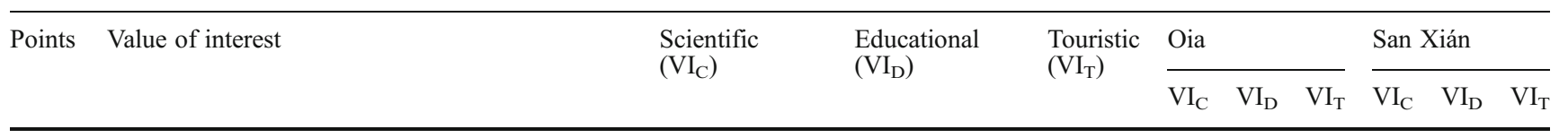

Representative quality

$1 \quad$ Useful as a model for partial representation $\quad \times 25$ of a feature or process

2 Useful as a model for full representation of $\quad \times 25$ a feature or process

4 The best known example, as far as the geological domain taken into account is concerned, to fully represent a feature or process

Character as a type locality

2 An internationally recognised site of reference (due to metallogenic, petrological, mineralogical, tectonic, stratigraphical, etc. reasons), or a typical site of fossils or biozones of wide scientific use

$4 \quad$ A stratotype accepted by the IUGS or an IMA type locality

Degree of scientific knowledge of the site

1 Published studies and/or doctoral theses exist $\quad \times 15$ concerning the site

2 The site has been researched by several scientific $\times 15$ groups and has been the object of doctoral theses and published studies referenced in national scientific journals

$4 \quad$ The site has been researched by several scientific groups and has been the object of doctoral theses and published studies referenced in international scientific journals

State of conservation

1 There is deterioration which prevents some interesting characteristics from being appreciated

2 There is some deterioration which does not significantly affect the value or degree of interest of the geosite

4 The geosite in question is in a good state of preservation, practically intact

$\times 20$

$\times 20$

$\times 5$

$\times 5$

$\times 0$

$\times 0$

$\times 20$

$\times 5$

$\times 0$

$\times 0$

$\times 0$

$\times 0$

$\times 15$

$\times 0$

$\times 0$

$60 \quad 0$

$\begin{array}{llllll}50 & 10 & 0 & 50 & 10 & 0\end{array}$

$\times 0$

Conditions of observation

$1 \quad$ With elements which mask the geosite and which prevent some interesting characteristics from being appreciated

2 With some elements which do not prevent the geosite from being observed in its entirety

$4 \quad$ Able to be easily and perfectly observed

$20 \quad 10 \quad 0$

Diversity (or international) level

1 The geosite possesses another type of interest, in addition to its principal feature, which is not relevant

2 The geosite possesses two types of interest, in addition to its principal feature, or only one which is relevant

4 The geosite possesses three or more types of interest, or only two more but both are relevant

Educational content

1 It illustrates contents of the university curriculum $\times 0$

2 It illustrates contents of the curriculum of any $\quad \times 0$ level of the educational system

4 It is frequently used in educational activities of $\quad \times 0$ any level of the educational system 
Table 2 (continued)

Points Value of interest
Scientific

$\left(\mathrm{VI}_{\mathrm{C}}\right)$
Educational

$\left(\mathrm{VI}_{\mathrm{D}}\right)$

\section{Touristic Oia \\ $\left(\mathrm{VI}_{\mathrm{T}}\right)$}

\begin{tabular}{|c|}
\hline Oia \\
\hline
\end{tabular}

Logistical infrastructure

1 Accommodation and restaurant for groups of up $\quad \times 0$ to 20 people less than $25 \mathrm{~km}$ away

2 Accommodation and restaurant for groups of up $\quad \times 0$ to 40 people less than $25 \mathrm{~km}$ away

4 Accommodation and restaurant for groups of $40 \times 0$ people less than $5 \mathrm{~km}$ away

Population density (potential immediate demand)

1 Less than 200,000 inhabitants within a radius $\quad \times 0$ of $50 \mathrm{~km}$

2 Between 200,000 and 1,000,000 inhabitants within a radius of $50 \mathrm{~km}$

4 More than $1,000,000$ inhabitants within a radius $\times 0$ of $50 \mathrm{~km}$

Accessibility

Not applicable

1 Direct access via unasphalted track suitable for $\quad \times 0$ use by vehicles

2 Direct access via asphalted road with coach park $\quad \times 0$

4 Direct access via unasphalted track suitable for $\quad \times 0$ use by vehicles Intrinsic fragility

1 Features measuring decametres in length which are not vulnerable due to visits but which are sensitive to other, more aggressive,

human activity

2 Features measuring hectometres in length which could undergo a certain degree of deterioration due to human activity

4 Features measuring kilometres in length which are unlikely to suffer deterioration due to human activity

Association with other elements of natural and/or cultural heritage

1 The presence of a single element of natural or $\quad \times 0$ cultural heritage within a radius of $5 \mathrm{~km}$

2 The presence of several elements of natural or cultural heritage within a radius of $5 \mathrm{~km}$

4 The presence of several elements of both natural $\times 0$ and cultural heritage within a radius of $5 \mathrm{~km}$

Spectacular nature or beauty

$0 \quad$ Not applicable

1 It is only used in touristic iconography on a $\quad \times 0$ local level

2 It is occasionally used in touristic iconography on a national or international level

4 It is frequently used in touristic iconography on a national or international level

Informative content

1 It instructs groups of a certain cultural level clearly and expressively

2 It instructs groups of any cultural level clearly and expressively on the importance and usefulness of geology

4 It is frequently used in informative content

Potential for carrying out touristic activities

1 It is possible to carry out one of these activities

2 It is possible to carry out both of these activities

4 These types of activities are organised regularly

Proximity to recreational areas (potential immediate demand)

1 Site located less than $5 \mathrm{~km}$ away from a

recreational area (camp sites, well-used beaches, national or natural parks, visitors centres, etc.)

2 Site located less than $2 \mathrm{~km}$ away from a recreational area

3 Site located less than $500 \mathrm{~m}$ away from a recreational area $\times 15$

$\times 15$

$\times 5$

$\times 5$

$\times 5$

$\times 5$

$\times 5$

0

30

$10 \quad 0$

30

10

$\times 5$

$\times 5$

$0 \quad 5$

5

0

$5 \quad 5$

$\times 5$

$\times 5$

$+2$

\section{$\begin{array}{lll}0 & 5 & 10\end{array}$}

$\times 10$

10

15

$0 \quad 5$

15

$\times 0$

$\times 0$

$\times 15$

$\times 0$

$\times 0$

$\times 0$

$\times 0$

$\times 0$

0

20

20

20

20

0

0

$0 \quad 0$

0

0

$\times 0 \times 5$


Table 2 (continued)

\begin{tabular}{|c|c|c|c|c|c|c|c|c|c|c|}
\hline \multirow[t]{2}{*}{ Points } & \multirow[t]{2}{*}{ Value of interest } & \multirow{2}{*}{$\begin{array}{l}\text { Scientific } \\
\left(\mathrm{VI}_{\mathrm{C}}\right)\end{array}$} & \multirow{2}{*}{$\begin{array}{l}\text { Educational } \\
\left(\mathrm{VI}_{\mathrm{D}}\right)\end{array}$} & \multirow{2}{*}{$\begin{array}{l}\text { Touristic } \\
\left(\mathrm{VI}_{\mathrm{T}}\right)\end{array}$} & \multicolumn{3}{|l|}{ Oia } & \multicolumn{3}{|c|}{ San Xián } \\
\hline & & & & & $\mathrm{VI}_{\mathrm{C}}$ & $\mathrm{VI}_{\mathrm{D}}$ & $\mathrm{VI}_{\mathrm{T}}$ & $\mathrm{VI}_{\mathrm{C}}$ & $\mathrm{VI}_{\mathrm{D}}$ & $\mathrm{VI}_{\mathrm{T}}$ \\
\hline \multicolumn{11}{|c|}{ Socio-economic environment } \\
\hline 1 & $\begin{array}{l}\text { Site located in a district with rates of per capita } \\
\text { income, education and employment which } \\
\text { are similar to the regional average but less } \\
\text { than the national average }\end{array}$ & $\times 0$ & $\times 0$ & $\times 10$ & 0 & 0 & 10 & 0 & 0 & 10 \\
\hline 2 & $\begin{array}{l}\text { Site located in a district with rates of per capita } \\
\text { income, education and employment which are } \\
\text { less than the regional average }\end{array}$ & $\times 0$ & $\times 0$ & $\times 10$ & & & & & & \\
\hline 4 & $\begin{array}{l}\text { Site located in a district with socio-economic } \\
\text { decline }\end{array}$ & $\times 0$ & $\times 0$ & $\times 10$ & & & & & & \\
\hline Totals & Scientific importance- $-\mathrm{I}_{\mathrm{C}}$ & $\begin{array}{l}\text { Educational } \\
\text { importance- } \mathrm{I}_{\mathrm{D}}\end{array}$ & $\begin{array}{l}\text { Touristic } \\
\text { importance- } \mathrm{I}_{\mathrm{T}}\end{array}$ & & & & & & & \\
\hline Oia & 215 & $185^{\circ}$ & 110 & & & & & & & \\
\hline $\begin{array}{l}\text { San } \\
\text { Xián }\end{array}$ & 235 & 195 & 110 & & & & & & & \\
\hline
\end{tabular}

radiocarbon facility of the Ångstrom Laboratory (Uppsala, Sweden) and the Centrum Voor Isotopen Onderzoek (Groningen). Conventional ${ }^{14} \mathrm{C}$ ages were calibrated using CALIB 6.0.1 (Stuiver and Reimer 1993; Reimer et al. 2009) using the Intcal09 dataset. As argued by Kaal et al. (2008a), the ${ }^{14} \mathrm{C}$ age of the organic matter in the studied soils is thought to be representative of the period in which the source vegetation died and the organic remains were incorporated into the soil (Pessenda et al. 2001; Kovda et al. 2001; Kaal et al. 2008a, b).

The deposits located in this area, as well as those in Mougás, have been the object of study since the end of the last century. In addition, samples have been taken from other deposits, such as those located in Oia, San Xián, Canela, Fedorento and A Guarda, with differing objectives by different researchers. The oldest radiocarbon datings were carried out on charcoal while the more recent ones have been performed on soil fine fractions (silt and clay) enriched in organic matter. Some of the old datings lack a laboratory code. Results are given in Table 1.

The results of the radiocarbon dating of the sequences of the Southern Coast studied here show that there is a relatively continuous sedimentary record from the middle of the Maximum Glacial (isotopic stage 2) to the Holocene. The Holocene period is well represented at a chronological level. The calibrated ages (at $2 \sigma$ ) which have been obtained show a temporal range from 1.7 to $11 \mathrm{Ka}$ cal BP. An interesting aspect about these data is that they also provide detailed chronological information for the Late Glacial period, with ages ranging from 11 to $14 \mathrm{Ka} \mathrm{BP}$; the Upper Maximum Glacial (isotopic stage 2), with ages ranging from 18 to $28 \mathrm{Ka} \mathrm{BP}$; and the isotopic stage 3, with ages of between 32 and $43 \mathrm{Ka} \mathrm{BP}$. The latter, obtained from the sequence of Fedorento, is the oldest one (Table 1). For ages older than $40 \mathrm{Ka} \mathrm{BP}$, the radiocarbon technique is not reliable, and other techniques would need to be used to have a greater certainty of the age of the sediments. In the older samples, there are chronological gaps. However, these gaps may also provide important information for the palaeoenvironmental reconstruction of the area because, on a climatic level, they can be related to generalised episodes, such as the Heinrich Events, in which facies related to erosive processes would predominate (Costa-Casais et al. 2007a, b, 2007-2008).

Methodological Proposal for the Drawing Up of an Inventory of Geosites

In order to carry out a methodological proposal, we followed the guidelines in the Methodological Document for the Drawing Up of the Spanish Inventory of Sites of Geological Interest of the Spanish Geological Survey (IGME) (García-Cortés and Carcavilla 2009). Although the entire coastal sector known as the Southern Coast is fossilised by ancient sedimentary deposits, for the purposes of this study, two sites have been selected as representative of the whole: Oia and San Xián (Figs. 1 and 3). The selection of sites of interest under each of the three categories (scientific, educational and touristic was carried out by applying fixed parameters for each type of value and corresponding coefficients giving each parameter a numerical value 1, 2 or 4 in terms of: representative value; character as a typical site; availability of scientific studies for the site; state of preservation; observation conditions; rarity; diversity; educational content/educational logistical infrastructure; population density (potential immediate demand); accessibility; intrinsic fragility; association with other elements of natural and/or cultural heritage; scenic value or beauty; informative content/informative use; potential for touristic activities; proximity to recreational areas (potential immediate demand) and socio-economical issues (García-Cortés and Carcavilla 2009) (Table 2). 
Table 3 Evaluation of the vulnerability of Oia Sur and San Xián geosites

\begin{tabular}{|c|c|c|c|c|}
\hline & Evaluation of vulnerability & Weighting & Value & \\
\hline Points & Human threats & & Oia & Xián \\
\hline 1 & $\begin{array}{l}\text { Site situated less than } 100 \mathrm{~m} \text { from a road, less than } 1 \mathrm{~km} \text { from industrial or } \\
\text { mining activity, less than } 2 \mathrm{~km} \text { from urban areas in towns of less than 100,000 } \\
\text { inhabitants or less than } 5 \mathrm{~km} \text { from bigger centres of population }\end{array}$ & $\times 15$ & 15 & 15 \\
\hline 2 & $\begin{array}{l}\text { Site adjacent to industrial or mining activity, adjacent to areas of possible future } \\
\text { urban construction or situated at less than } 25 \mathrm{~m} \text { from a road }\end{array}$ & $\times 15$ & & \\
\hline 4 & $\begin{array}{l}\text { Site located in a mine (either active or abandoned), on the verge of a road or in an } \\
\text { urban area }\end{array}$ & $\times 15$ & & \\
\hline Points & Interest for mining exploitation & & 0 & 0 \\
\hline 1 & Substance of low or moderate interest and which is already being mined in the area & $\times 15$ & & \\
\hline 2 & Substance of high interest and which is already being mined in the area & $\times 15$ & & \\
\hline 4 & Substance of high interest which is not being mined at any other site in the area & $\times 15$ & & \\
\hline Points & Natural threats & & & \\
\hline 1 & Feature(s) vulnerable to meteorisation & $\times 15$ & & \\
\hline 2 & Site affected by active processes (erosion, flooding, landslides, etc.) of moderate intensity & $\times 15$ & 30 & 30 \\
\hline 4 & Site affected by intense active processes (erosion, flooding, landslides, etc.) & $\times 15$ & & \\
\hline Points & Intrinsic fragility & & & \\
\hline 1 & $\begin{array}{l}\text { Features measuring kilometres in length which could suffer a certain degree of } \\
\text { deterioration due to human activity }\end{array}$ & $\times 10$ & & \\
\hline 2 & $\begin{array}{l}\text { Features measuring decametres in length which are not vulnerable to visits but } \\
\text { which are sensitive to other, more aggressive human activity }\end{array}$ & $\times 10$ & 20 & 20 \\
\hline 4 & Paleontological or mineralogical sites which are prone to pillaging & $\times 10$ & & \\
\hline Points & Protection regime of the site & & & \\
\hline 1 & $\begin{array}{l}\text { Protected site but not subject to a planning programme and with no surveillance. } \\
\text { Also a site of cultural interest due to its paleontological/archaeological content }\end{array}$ & $\times 10$ & & \\
\hline 2 & $\begin{array}{l}\text { Site situated in a rural area, protected from urbanisation by territorial and urban } \\
\text { planning programmes }\end{array}$ & $\times 10$ & & \\
\hline 4 & Site lacking any type of official protection & $\times 10$ & 40 & 40 \\
\hline Points & Physical or indirect protection & & & \\
\hline 1 & $\begin{array}{l}\text { An easily accessible site in spite of being situated away from paths and camouflaged } \\
\text { by vegetation }\end{array}$ & $\times 10$ & & 10 \\
\hline 2 & An easily accessible site only camouflaged by vegetation & $\times 10$ & 20 & \\
\hline 4 & Site lacking any type of indirect protection & $\times 10$ & & \\
\hline Points & Accessibility (potential aggression) & & & \\
\hline 1 & Direct access via unasphalted track suitable for use by vehicles & $\times 10$ & & 10 \\
\hline 2 & Direct access via asphalted road with car park & $\times 10$ & 20 & \\
\hline 4 & Direct access via asphalted road with coach park & $\times 10$ & & \\
\hline Points & Ownership regime of the site & & & \\
\hline 1 & Site located in publicly owned areas with restricted access & $\times 5$ & & \\
\hline 2 & Site located in privately owned areas with restricted access & $\times 5$ & & \\
\hline 4 & Site located in privately owned areas or privately owned areas with free access & $\times 5$ & 20 & 20 \\
\hline Points & Population density (potential aggression) & & & \\
\hline 1 & More than 100,000 but less than 200,000 inhabitants within a radius of $50 \mathrm{~km}$ & $\times 5$ & 5 & 5 \\
\hline 2 & Between 200,000 and 100,000 inhabitants within a radius of $50 \mathrm{~km}$ & $\times 5$ & & \\
\hline 4 & More than $1,000,000$ inhabitants within a radius of $50 \mathrm{~km}$ & $\times 5$ & & \\
\hline Points & Proximity to recreational zones (potential aggression) & & & \\
\hline 1 & Site located less than $5 \mathrm{~km}$ from a recreational area (camp sites, well-used beaches, etc.) & $\times 5$ & & 5 \\
\hline 2 & Site located less than $2 \mathrm{~km}$ from a recreational area & $\times 5$ & 10 & \\
\hline 4 & Site located less than $500 \mathrm{~m}$ from a recreational area & $\times 5$ & & \\
\hline Total vulnerability (V) & & 180 & 155 & \\
\hline
\end{tabular}


The evaluation of the vulnerability of the selected geosites was carried out according to the following parameters, each one being given a value of 1,2 or 4 : human threats, natural threats, intrinsic fragility, the protection regime, indirect protection, accessibility (potential impact), ownership regime, population density and proximity to recreational areas (potential impact ) (García-Cortés and Carcavilla 2009) (Table 3). Following the collection of data and fieldwork, the next step was to evaluate the geosites. Each one was evaluated under the above-listed parameters, which were given varying weight in order to evaluate their scientific, educational and touristic interest. Sites with values higher than 200 were considered to be of high interest; between 101 and 200, of average interest; and with 101 or less, of low interest and thus not proposed for the Spanish Inventory of Geosites. Once the geosites had been selected and their values calculated, we analysed the degree of prioritisation of their protection. This was carried out by applying parameters of evaluation aimed at establishing the state of vulnerability of each geosite and assigning an objective score to each one in order to establish their ranking. To obtain the state of Protection Priority $\left(\mathrm{PP}_{\mathrm{G}}\right)$ of each geosite, the "V" parameter (vulnerability) must be added to the "I" parameter, which corresponds to its scientific, educational and touristic interest, as shown in the formula in Table 4.

Those geosites which obtained a $\mathrm{PP}_{\mathrm{G}}$ value higher than 500 are considered to be in need of urgent protection. If the $\mathrm{PP}_{\mathrm{G}}$ value is between 201 and 500, protection is recommended in the medium term. However, if the $\mathrm{PP}_{\mathrm{G}}$ is lower than 201, the geosite does not need urgent protection (García-Cortés and Carcavilla 2009).

\section{Results and Discussion}

\section{General Observations}

The irregular outline of the Galician coast and the presence of coastal mountain ranges of c. $600 \mathrm{~m}$ in altitude favoured the development, during the Late Pleistocene, of a morphogenetic environment dominated by cold processes. The end result was the accumulation of sedimentary material of continental origin in areas prone to sedimentation, as can be observed on the Southern Coast (see the geomorphological map in Fig. 3). Coastal formations carved out in transgressive episodes, such as shore platforms and pebble and boulder beaches, were fossilised by these continental deposits during the regressive episodes. The specific factors which controlled the formation and the type of deposit were: humidity coming off the ocean, height of the coastal mountains and the gradient of the slopes and their distance from the source area. Today, they function as active cliffs of unconsolidated sedimentary material of which only the part closest to the source is preserved (Costa-Casais 2001). Their main source area is the mountain range of A Groba and the foothills of $\mathrm{O}$ Argallo (Fig. 3), but there are differences between those located in the estuaries of rivers and streams and those situated on the straight coast, with the former reaching $12 \mathrm{~m}$ in thickness in some cases. Those which developed on a flat surface are more homogeneous, both vertically and horizontally and show lower thicknesses (1$3 \mathrm{~m}$ ), with sedimentary facies dominated by layers rich in organic matter. Remnants of palaeosols are exposed on top of the shore platform and infilling rock fractures. Coastal retreat was more intense in sectors exposed than in those protected (so-called "ports" or inlets) from the direct erosion of wave action. The latter have higher vegetation cover and present a greater variety of facies. The deposits are not only fossilise the coast, but they also extend up the slopes, their thickness decreasing on the hillsides but maintained as a sedimentary cover on the floor of the valleys (Costa-Casais 2001; Costa-Casais et al. 2002, 2005). We have inventoried a total of 47 deposits along the sector of the Southern Coast (Fig. 3). Relevant information for each one is provided in Table 5.

\section{Colluvial Layers of Coarse Material and Soil Dynamics}

According to the distance of the mountains from the coast and the gradient and degree of channel dissection of the intervening area (Pérez et al. 1998), two types of deposits can be distinguished in the Southern Coast: (a) Deposits infilling valleys located close to the mountains, with their central portions filled with alternating coarse debris and sandy, organic-rich sediment layers; (b) where the mountains are distant from the coast, the intervening topography is not usually dissected by valleys and the coastal sediments are predominantly fine-grained and less than 2-3 $\mathrm{m}$ in thickness (Costa-Casais 2001; CostaCasais et al. 2005) (Fig. 4).

Table 4 Vulnerability (V), interest (I) and protection priority (PP) for each geosite: formula to obtain the different types of protection priority

V, Vulnerability

$\mathrm{I}_{\mathrm{C}}$, Scientific interest

$\mathrm{I}_{\mathrm{D}}$, Educational interest $\quad \mathrm{PP}_{\mathrm{C}}=\mathrm{I}_{\mathrm{C}}+\mathrm{V}$

$\mathrm{I}_{\mathrm{T}}$, Tourist interest

$\mathrm{PP}_{\mathrm{D}}=\mathrm{I}_{\mathrm{D}}+\mathrm{V}$

$\mathrm{PP}_{\mathrm{C}}=$ Scientific protection priority

$\mathrm{PP}_{\mathrm{T}}=\mathrm{I}_{\mathrm{T}}+\mathrm{V}$

$\mathrm{PP}_{\mathrm{D}}=$ Educational protection priority

$\mathrm{PP}_{\mathrm{G}}=\left[\left(\mathrm{I}_{\mathrm{C}}+\mathrm{I}_{\mathrm{D}}+\mathrm{I}_{\mathrm{T}}\right) / 3\right]+\mathrm{V}$

$\mathrm{PP}_{\mathrm{T}}=$ Tourist protection priority

$\mathrm{PP}_{\mathrm{G}}=$ Global protection priority 
Table 5 Geomorphological features of the studied deposits located between Cape Silleiro and A Guarda: thickness, relation with other landforms, aerial view of coastal landforms and potential source area

\begin{tabular}{|c|c|c|c|c|}
\hline Deposits, location and references & Thick (m) & $\begin{array}{l}\text { Deposits relation with } \\
\text { other landforms }\end{array}$ & $\begin{array}{l}\text { Coastal landforms } \\
\text { (aerial view) }\end{array}$ & Potential source area \\
\hline 1. A Selas & 6 & Attached to the slope & Embayment & Upper Cape Silleiro \\
\hline 2. As Voltas & 4 to 6 & Attached to the slope & Embayment & Upper Cape Silleiro \\
\hline 3. A) As Mariñas-A Ermida & 1 & $\begin{array}{l}\text { On the coastal shore } \\
\text { platform }\end{array}$ & Straight coast & Outcrops: Loudrelos, do Home \\
\hline 4. B) As Mariñas-A Ermida & 0.5 to 0.7 & $\begin{array}{l}\text { On the coastal shore } \\
\text { platform }\end{array}$ & Straight coast & Outcrops: Loudrelos, do Home \\
\hline 5. C) As Mariñas-A Ermida & 1 & $\begin{array}{l}\text { On the coastal shore } \\
\text { platform }\end{array}$ & Straight coast & Outcrops: Loudrelos, do Home \\
\hline 6. North of A Ermida & 1 & Attached to the slope & Straight coast & Nearby slopes \\
\hline 7. A Ermida & 10 to 12 & Attached to the cliff & Embayment & Mount: Os Pousos \\
\hline 8. A) Pta. Centinela-Pedra Rubia & 8 to 10 & Attached to the slope & Open embayment & Mount: Alto do Facho \\
\hline 9. B) Pta. Centinela-Pedra Rubia & 8 to 10 & Attached to the slope & Open embayment & Mount: Alto do Facho \\
\hline 10.C) Pta. Centinela-Pedra Rubia & 8 & Attached to the cliff & Embayment & Mount: Alto do Facho \\
\hline 11. Pedra Rubia-O Cagado & 1 & $\begin{array}{l}\text { On the coastal shore } \\
\text { platform }\end{array}$ & Straight coast & Nearby slopes \\
\hline 12. A) Barcelos: Os Muíños & 8 & Attached to the cliff & Embayment & Upper Oliveira Mountain \\
\hline 13. B) Barcelos & 8 to 9 & Attached to the cliff & Embayment & Mount: Alto da Oliveira \\
\hline 14. C) Barcelos & 8 to 9 & Embayment & Embayment & Mount: Alto da Oliveira \\
\hline 15. South Barcelos-Porto Mougás & 2 to 3 & Attached to the slope & Straight coast & Nearby slopes \\
\hline 16. Porto Mougás & 1 to 2 & Flat surface & $\begin{array}{l}\text { Embayment or } \\
\text { "Porto" }\end{array}$ & River Mougás \\
\hline 17. A)Porto Senín & 2 & Flat surface & $\begin{array}{l}\text { Embayment or } \\
\text { "Porto" }\end{array}$ & River: Vila de Suso \\
\hline 18. B) Porto Senín & 2 to 3 & Flat surface & $\begin{array}{l}\text { Embayment or } \\
\text { "Porto" }\end{array}$ & River: Vila de Suso \\
\hline 19. C) Porto Senín & 2 to 3 & Flat surface & $\begin{array}{l}\text { Embayment or } \\
\text { "Porto" }\end{array}$ & River: Vila de Suso \\
\hline 20. D) Porto Senín & 8 to 10 & Flat surface & $\begin{array}{l}\text { Embayment or } \\
\text { "Porto" }\end{array}$ & River: Vila de Suso \\
\hline 21. Porto Senín-Os Loureiros & 7 & Flat surface & Sinuous embayment & A Cruz de Pau \\
\hline 22. Os Loureiros North & 1 to 1.5 & Attached to the slope & Sinuous embayment & Nearby slopes \\
\hline 23. Os Loureiros South & $7-8$ & Attached to the slope & Sinuous embayment & A Cruz de Pau \\
\hline 24. Os Loureiros-Porto Canela & 0.5 to 1 & Shore platform and boulders & Straight coast & Nearby slopes \\
\hline 25. Porto Canela, North & $\begin{array}{l}0.8 / 0.9 \text { to } \\
1.5\end{array}$ & $\begin{array}{l}\text { On the coastal shore } \\
\text { platform }\end{array}$ & Open embayment & Mount: Penizas \\
\hline 26. Porto Canela, South & 1 & $\begin{array}{l}\text { On the coastal shore } \\
\text { platform }\end{array}$ & Open embayment & Mount: Penizas \\
\hline $\begin{array}{l}\text { 27. A) Margin South of Porto } \\
\text { Canela }\end{array}$ & 1 to 2 & $\begin{array}{l}\text { On the coastal shore } \\
\text { platform }\end{array}$ & Sinuous embayment & Mounts: Penizas, Morogueiras \\
\hline $\begin{array}{l}\text { 28. B) Margin South of Porto } \\
\text { Canela }\end{array}$ & 0.7 to 0.8 & $\begin{array}{l}\text { On the coastal shore } \\
\text { platform }\end{array}$ & Sinuous embayment & Mounts: Penizas, Morogueiras \\
\hline 29. Vilar & 2 to 3 & $\begin{array}{l}\text { On the coastal shore } \\
\text { platform }\end{array}$ & Straight coast & Mount: Mendes \\
\hline 30. A) Ribasaltas & 5 to 7 & Attached to the slope & Small embayment & Mount: Mendes; River: Vilar \\
\hline 31. B) Ribasaltas & 7 to 10 & Attached to the slope & Small embayment & Mount: Mendes; River: Vilar \\
\hline 32. C) Ribasaltas & 7 to 10 & Attached to the slope & Small embayment & Mount: Mendes; River: Vilar \\
\hline 33. Oia & 8 to 10 & Attached to the slope & Closed embayment & $\begin{array}{l}\text { Alto do Castro, Labandeira } \\
\text { creek }\end{array}$ \\
\hline 34. Cala Redondeliño & 8 to 10 & Attached to the slope & Open embayment & Alto do Castro, Aguieira creek \\
\hline 35. Porto da Fonte das Mañas & 8 & Attached to the slope & Small embayment & Mount: Valga \\
\hline 36. A) O Forno & 5 to 6 & Attached to the slope & Straight coast & A Cruz do Carqueixedo \\
\hline 37. B) O Forno & 5 to 6 & Attached to the slope & Straight coast & A Cruz do Carqueixedo \\
\hline 38. C) O Forno & 2 & Attached to the slope & Straight coast & Alto da Poza \\
\hline
\end{tabular}


Table 5 (continued)

\begin{tabular}{|c|c|c|c|c|}
\hline Deposits, location and references & Thick (m) & $\begin{array}{l}\text { Deposits relation with } \\
\text { other landforms }\end{array}$ & $\begin{array}{l}\text { Coastal landforms } \\
\text { (aerial view) }\end{array}$ & Potential source area \\
\hline 39. A) San Xián & 5 to 6 & Attached to the slope & Straight coast & Alto da Poza, Cova river \\
\hline 40. B) San Xián & 10 & Attached to the slope & Straight coast & Alto da Poza, Cova river \\
\hline 41. C) San Xián & 10 to 15 & Attached to the slope & Straight coast & Alto da Poza, Cova river \\
\hline 42. Portocelo & 8 to 10 & Attached to the slope & Small embayment & Campo do Torroso \\
\hline 43. Porto Amiadelo-Escuma & 2 to 3 & $\begin{array}{l}\text { On the coastal shore } \\
\text { platform }\end{array}$ & Straight coast & Nearby slopes \\
\hline 44. A Lamosa & 8 & Cave, cliff & Sinuous embayment & Alto do Torroso \\
\hline 45. O Torroso & 30 to 50 & $\begin{array}{l}\text { On the coastal shore } \\
\text { platform }\end{array}$ & Straight coast & Nearby slopes \\
\hline 46. Cala da Cetárea & $1-2 \mathrm{~m}$ & $\begin{array}{l}\text { On the coastal shore } \\
\text { platform }\end{array}$ & Straight coast & Nearby slopes \\
\hline 47. Fedorento & $8-10 \mathrm{~m}$ & Attached to the cliff & Closed embayment & Slopes and flat surfaces \\
\hline
\end{tabular}

Coarse grain-sized colluvial layers are interspersed with palaeosols of finer material. As mentioned above, nival and periglacial activity were responsible for the formation of most of the colluvial layers, which tend to overlap producing a great complexity of facies. The most important formations, linked to processes of fusion and cryogenesis, are simple and complex palaeochannels and wide cross-bed structures of coarse rounded or subrounded, oriented, overlapping material with different degrees of weathering. The size of the palaeochannels is variable, reaching up to 1$2 \mathrm{~m}$ in both width and height. They also show cut and fill structures that were generated by rapid, non-turbulent flows of snow fusion. Other formations related to fusion processes include debris flow (gelifluction and laminar solifluction), which are characterised by the alternation of fine and coarse material. At times of greater stability, fine material with a variable content of organic material was deposited on the hill slopes, whilst, when fusion processes were active, rapid flows of water were generated which carried away vast quantities of material. The fine material was more easily eroded, but the coarse material stayed close to the slope resulting in the genesis of stratified, granoclassified, oriented and overlapping layers (Costa-Casais 2001; Blanco-Chao and Costa-Casais 2001).

The most representative formations and periglacial processes are the gelifluidal and solifluidal facies of the head type, composed of pebbles and sands, tightly packed into a silty clay matrix. The material is well ordered and, in many cases, lies parallel to the slope. According to Van VlietLanöe and Valadas (1983), these formations can be used as palaeoclimatic indicators, as the sands reveal the existence of deep seasonal ice with a high degree of humidity and the coarse material proves the presence of permafrost under cold and dry climatic conditions.

The palaeosols are rich in organic matter and also contain thin gravel and charcoal layers (Fig. 4). These soils reflect periods of slope stability at a time of widespread cold conditions. They have variable thicknesses and well-defined pedofeatures and represent a recurrent facies throughout the whole sector. They are only absent in places where erosion preceded the formation of the colluvial layers (palaeochannels, cross-bed structures and debris flow or lines of gravel) (Fig. 4). Van Vliet-Lanöe (1988, 1990a, b) interprets their presence, such as those located in Britanny (France), as reflecting wetter periods.

The fossilisation of the palaeosols in colluvial material either slowed down or stopped their pedogenetical evolution. Therefore, their properties reflect the dominant environmental conditions when they were at the surface (Martínez-Cortizas and Moares 1995). Soil formation may have occurred in periods of climate amelioration, which would favour pedogenesis, under overall cold conditions (Costa-Casais et al. 1996b; Costa-Casais 2001; Pérez et al. 1998, 1999; Blanco-Chao et al. 2002, 2003). During periods of climatic deterioration, they were partially eroded, and the resulting material was transported and deposited in lower topographical regions by short, repetitive laminar flows, which also generated stone, gravel and charcoal lines and iron mottling (Fig. 4). The radiocarbon dates we obtained indicate that the oldest sediments were deposited around $40 \mathrm{Ka}$ BP (Table 1). The physico-chemical properties of the sediments are suggestive of intense chemical/mineral alteration in periods of paleosol formation (Costa-Casais et al. 1994; Costa-Casais et al. 2007-2008).

\section{Examples of the Deposits of Oia Sur and San Xián}

As there is a wide range of sedimentary deposits in the Southern Coast (Table 5), we used a set of criteria to select representative ones, namely: location and proximity to the mountain range; presence/absence of valleys reaching the coast; presence of vegetation cover on the deposit; total thickness; continuity in sedimentation; variety of sedimentary 
Fig. 4 Photos of the Southern Coast. a This stretch of coast is characterised by its rectilinear layout and the main source area is the mountain range: Groba and $\mathrm{O}$ Argallo; $\mathbf{b}$ and $\mathbf{c}$ the deposits fossilise the coast and extend up the slopes with coarser material; $\mathbf{d}$ deposit of Barcelos (Os Muiños): The most important formations linked to processes of fusion and cryogenics are palaeochannels and wide crossbed structures of coarse material developed between organic levels; e sampling of the Oia deposit; $\mathbf{f}$ the palaeosols are composed of fine material (sands, silts and clays) are rich in organic matter and include gravels and charcoal; $\mathbf{g}$ and $\mathbf{i}$ collection of samples in two sectors of the deposit of Oia Sur; h Deposit of Porto Senín: deposits infilling valleys located close to the mountains and the central portions are filled with coarse debris; $\mathbf{j}$ iron mottles in the palaeosol
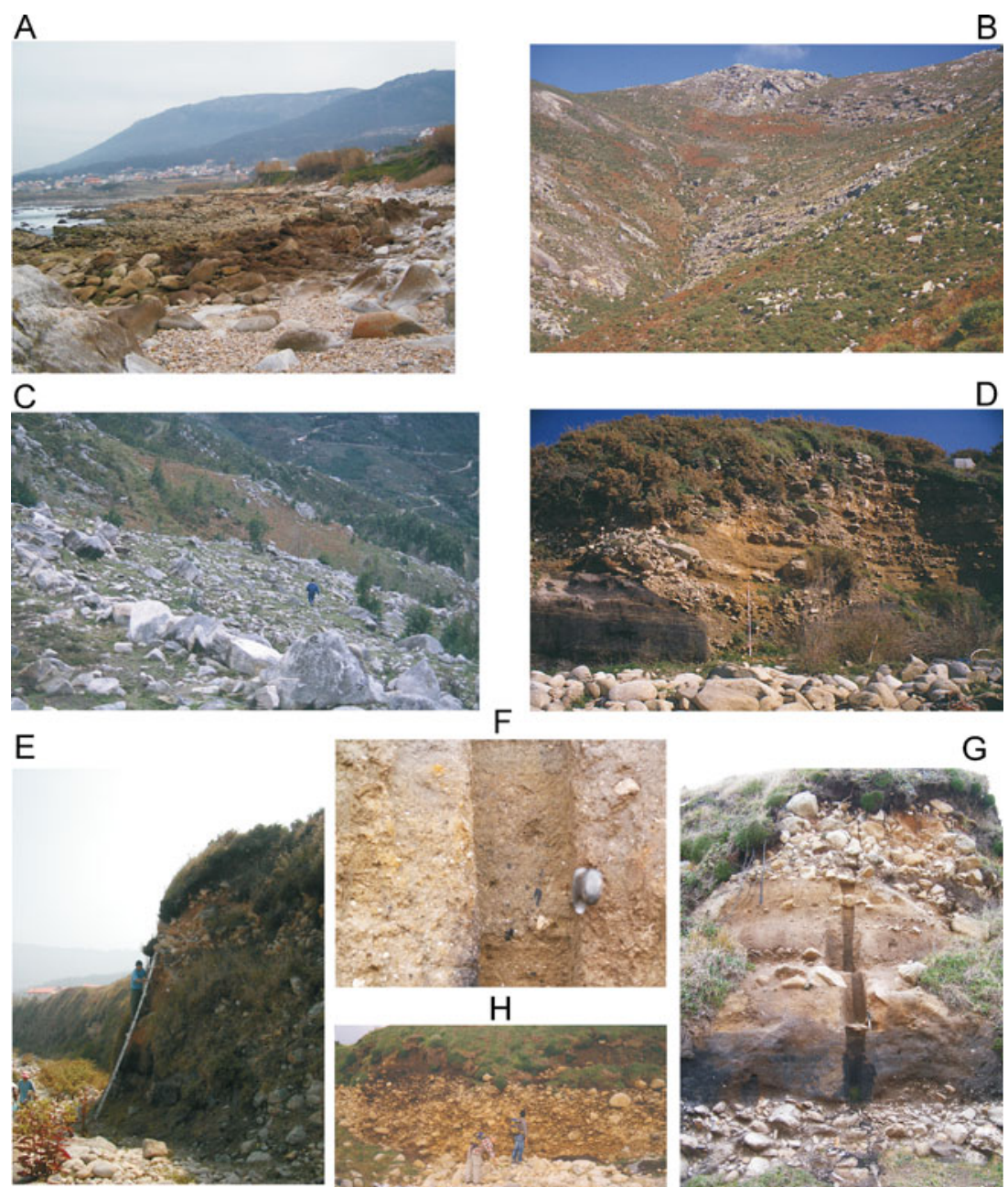

$\mathrm{H}$

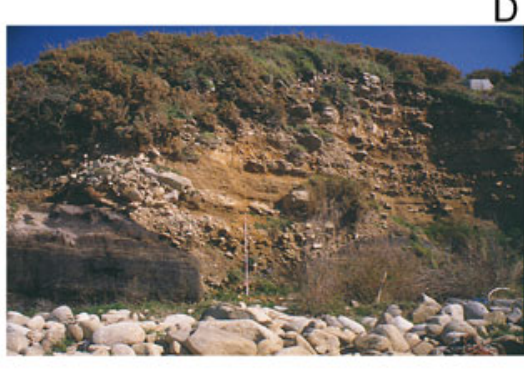

D
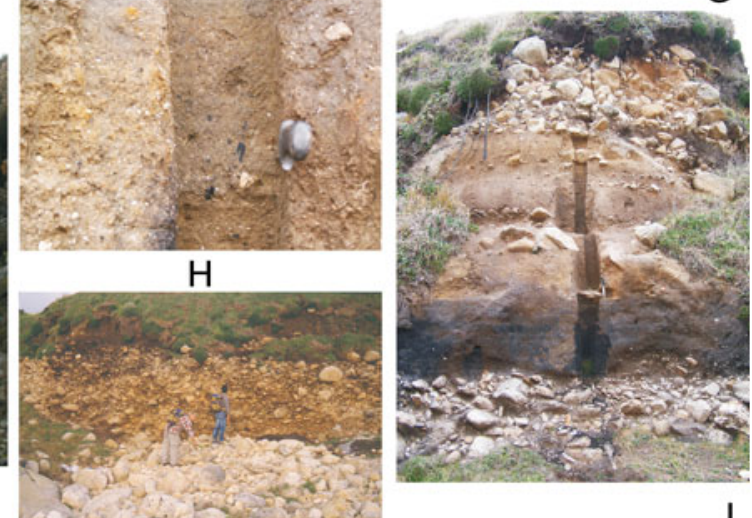

I
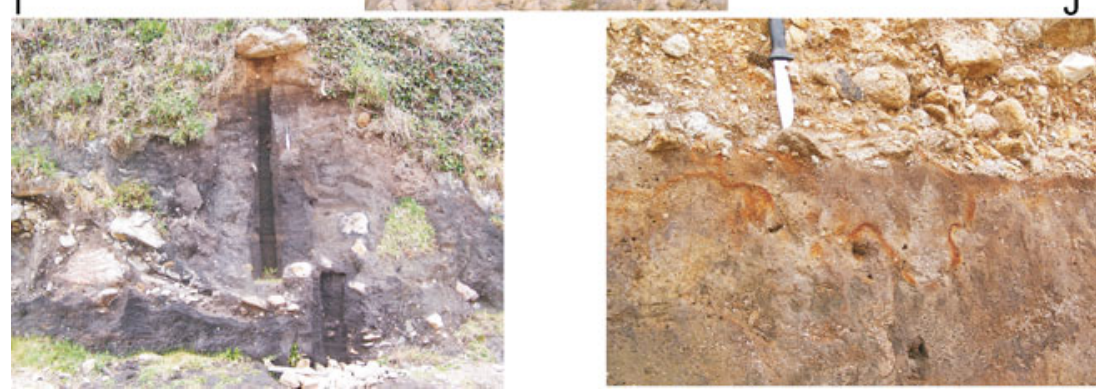

facies and location in relation to other coastal formations (the shore platform and boulder beaches). After analysing and evaluating all these features, the deposits of Oia Sur, located between the bays of Redondeliño and Redondelo, and that of

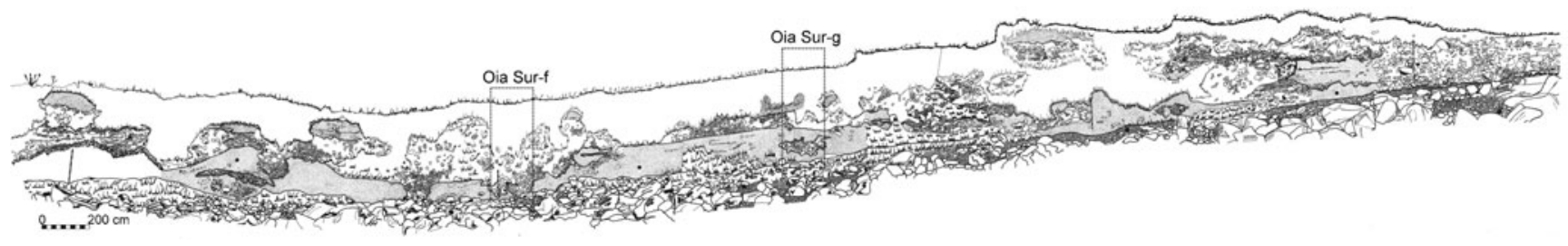

Fig. 5 Drawing of the longitudinal and vertical development of the deposit of Oia Sur. The asterisk symbol indicates the palaeosols. This drawing shows the location of the stratigraphic columns described in Fig. 6 
Fig. 6 Sedimentological and stratigraphic columns of two profiles sampled in the deposit Oia Sur $(f$ and $g)$
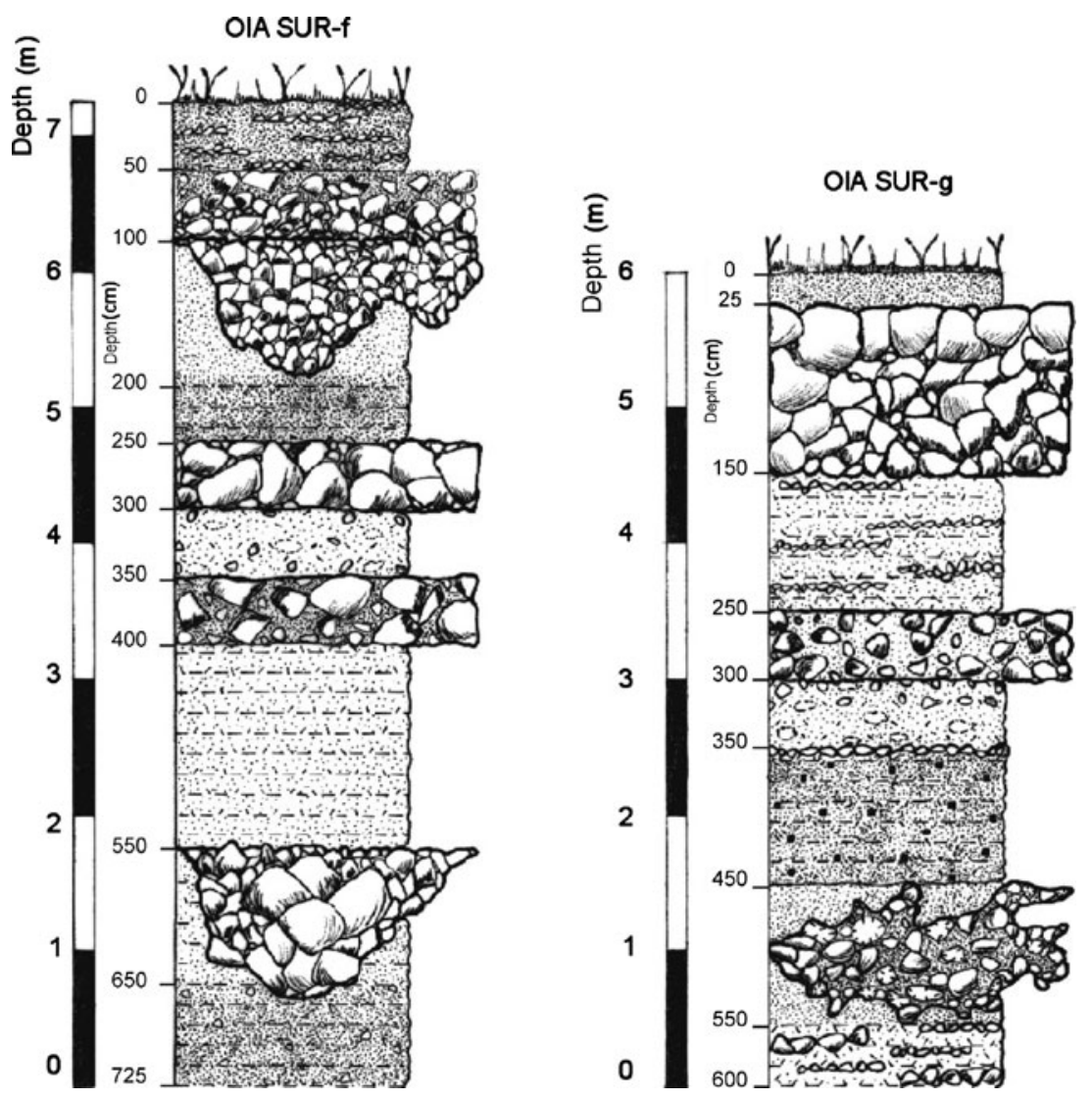

San Xián, located between Pena Agoeira and Portocelo Bay (Fig. 3) were chosen.

The main facies which have been described are periglacial and nivo-fluvial in nature, alternating with palaeosols of fine material. The radiocarbon dating measurements obtained for the palaeosols contextualise chronologically the data provided by morpho-sedimentary and physicochemical analysis.

\section{Oia Sur Deposit}

This is representative of a distal (far from the source area) sedimentary formation, dominated by fine material, in an area that had a main river with a relatively wide valley and slopes of low inclination. The outline of the coast is irregular, and there is a shore platform of $80-90 \mathrm{~m}$ in width, which reduces to $50-60 \mathrm{~m}$ in the inlets, with a slight inclination towards the sea and an extremely irregular inhomogeneous surface in which three levels of deposition can be defined (Blanco-Chao 1999). The inner part of the inlet has a higher inclination. The sedimentary deposit covers the platform with a greater thickness in its centre $(8 \mathrm{~m})$ than at the sides $(5-6 \mathrm{~m})$. It is a cliff that is actively retreating along the sides, at its southernmost part in particular, due to storms and the winter activity of the stream in the Aguieira Valley. The eroded material is washed out by

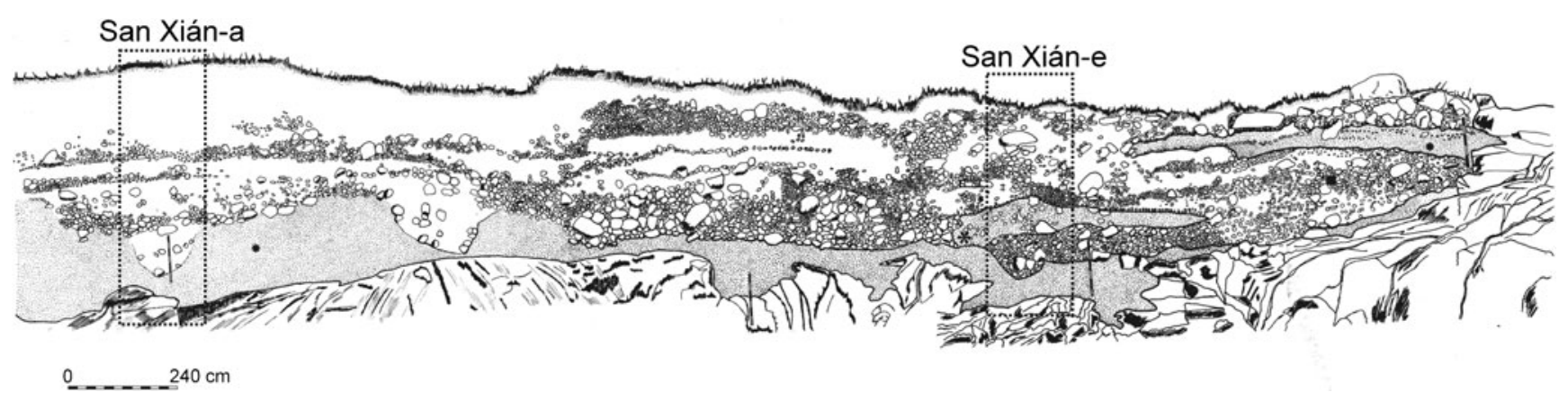

Fig. 7 Drawing of the longitudinal and vertical development of the deposit of San Xián. The asterisk symbol indicates the palaeosols. This drawing shows the location of the stratigraphic columns described in Fig. 8 
the sea, which reworks the clasts and incorporates them into the gravel and pebble beach located within the inlet. It is a polycyclic deposit of continental origin, with differences in both vertical and horizontal deposition, as can be seen in Figs. 5 and 6.

\section{San Xián Deposit}

This is representative of a proximal deposit (close to the source area), dominated by coarse material, in an area of higher inclination with short, deeply incising, rivers. As in Oia Sur, the sediments fossilise the shore platform and other marine (possibly inherited) polished landforms. It is fairly continuous, reaching thicknesses of 7-8 $\mathrm{m}$ at the centre of the inlet and 5-6 $\mathrm{m}$ at the sides. At its northernmost point, the deposit is extensively covered by vegetation, whilst towards the south it shows erosional features. The erosion of the sediments favours the formation of gravel, pebble and boulder beaches at the front of the deposit. It is also a polycyclic deposit of continental origin, with differences in both vertical and horizontal deposition, as can be seen in Figs. 7 and 8.

\section{Chronological Context and Heinrich Events}

The inventory and analysis of the variability of the colluvial sedimentary facies of the deposits, which were generated by cold processes, enable them to be correlated with Heinrich Events (HE) (Duplessy et al. 1981; Heinrich 1988). Radiocarbon dating has allowed them to be placed within the chronological framework of the Late Pleistocene and with the HE in particular (Costa-Casais et al. 2009; Valcárcel and Costa-Casais 2011; Valcárcel et al. 2011). In a literature review, we have found 30 datings for the Southern Coast, most of them from soil organic matter of paleosols underlying and overlying the coarse colluvial
Fig. 8 Sedimentological and stratigraphic columns of two profiles sampled in the deposit San Xián $(a$ and $e$ )

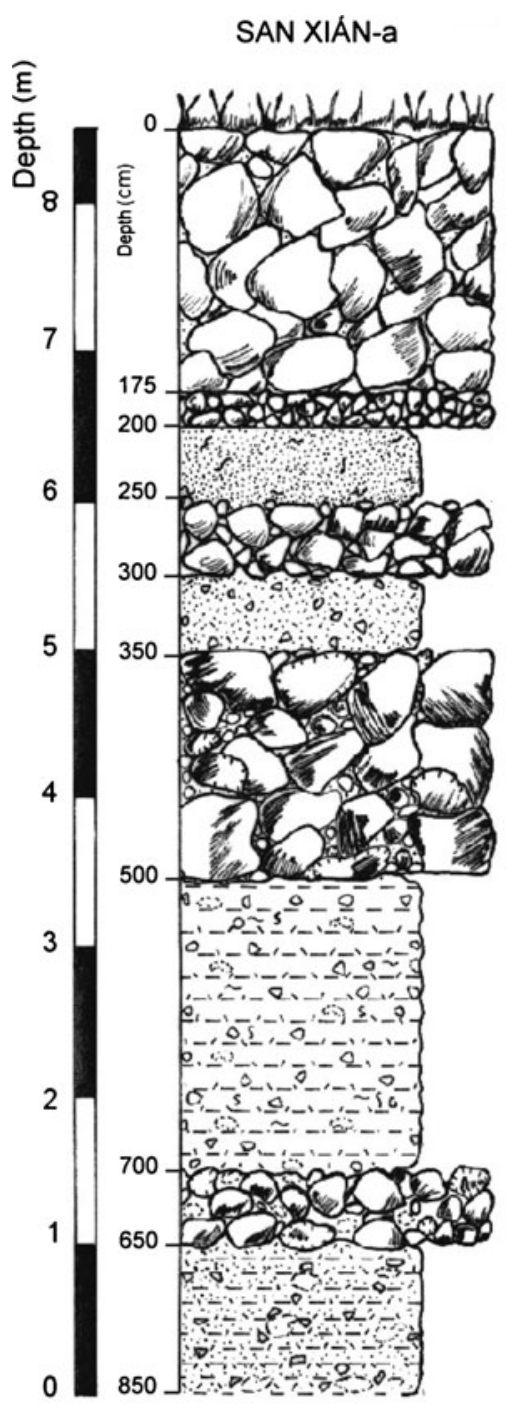

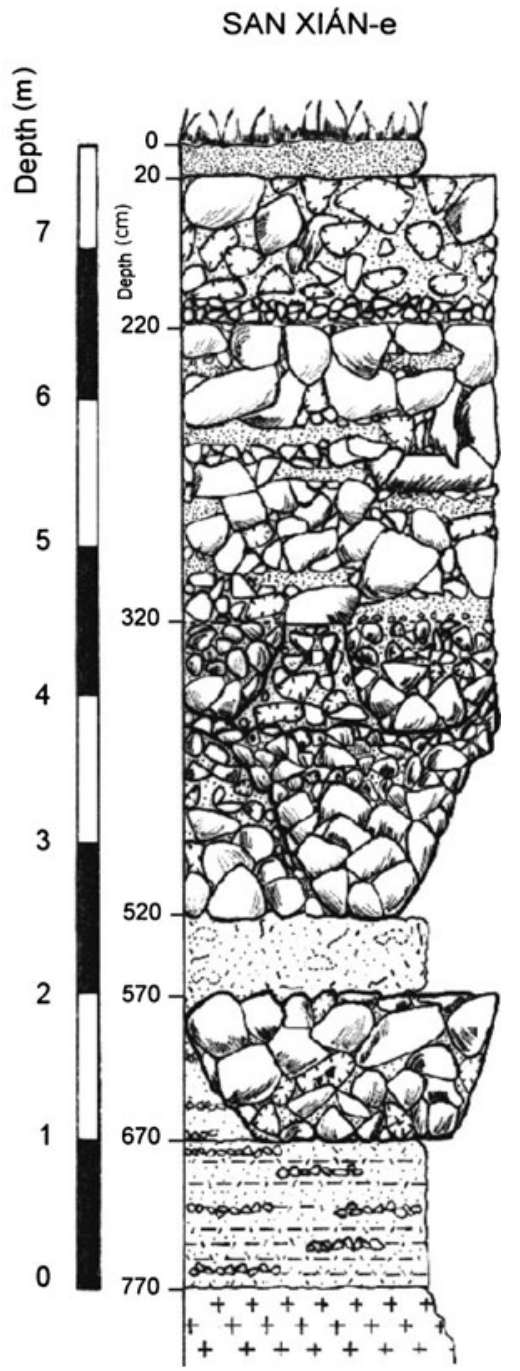


layers, although some were carried out on charcoal, as shown in Table 1. The oldest ages (43-38 Ka BP) were obtained at the base of the deposits (Fig. 9). Taking into account the documented ages, it can be stated that there is a fairly continuous chronological record for the Late Pleistocene. Chronological gaps correspond to the 2a (23.5 Ka BP) and 1a (16 Ka BP) Heinrich Events that are represented by coarsegrained colluvial layers, for which radiocarbon dating was not possible (Bard et al. 2004; Costa-Casais et al. 2009). The obtained dates also show a good record for the Holocene in most deposits (from 11 to $1.7 \mathrm{Ka}$ cal BP). For these Holocene aged sandy, acidic, organic matter-rich colluvial soils, both climatic changes and human activities have been proposed as drivers of their formation (Costa-Casais et al. 2008; 2009; Martínez-Cortizas et al. 2009) (Fig. 9).

From the end of the last century to the present day, this part of the Galician coast has been a reference study area for several research teams with very different environmental or archaeological objectives. This is also reflected in the references in Table 1. The information accompanying each radiocarbon dating differs between authors, as does the type of material that has been dated and the depth at which the sample was collected, amongst other things. There is a number of uncertainties which necessitates much care in the interpretation of these ages. Not many of the datings were carried out on well referenced, both stratigraphically and physico-chemically, layers (Fig. 9). Their comparison with other records, and therefore with other dating results, will help to define the chronology of erosional and depositional processes for the whole sector.

Proposal for the Assessment of the Protection Priority of the Selected Deposits, Oia Sur and San Xián

The Quaternary deposits of Oia Sur and San Xián were selected as the most representative of the Southern Coast and should be considered as geosites, in terms of their scientific value as based on geomorphological, stratigraphical, sedimentological, pedological and other criteria.

In applying the criteria above to assess the degree of importance of the sites of geological interest, Oia Sur

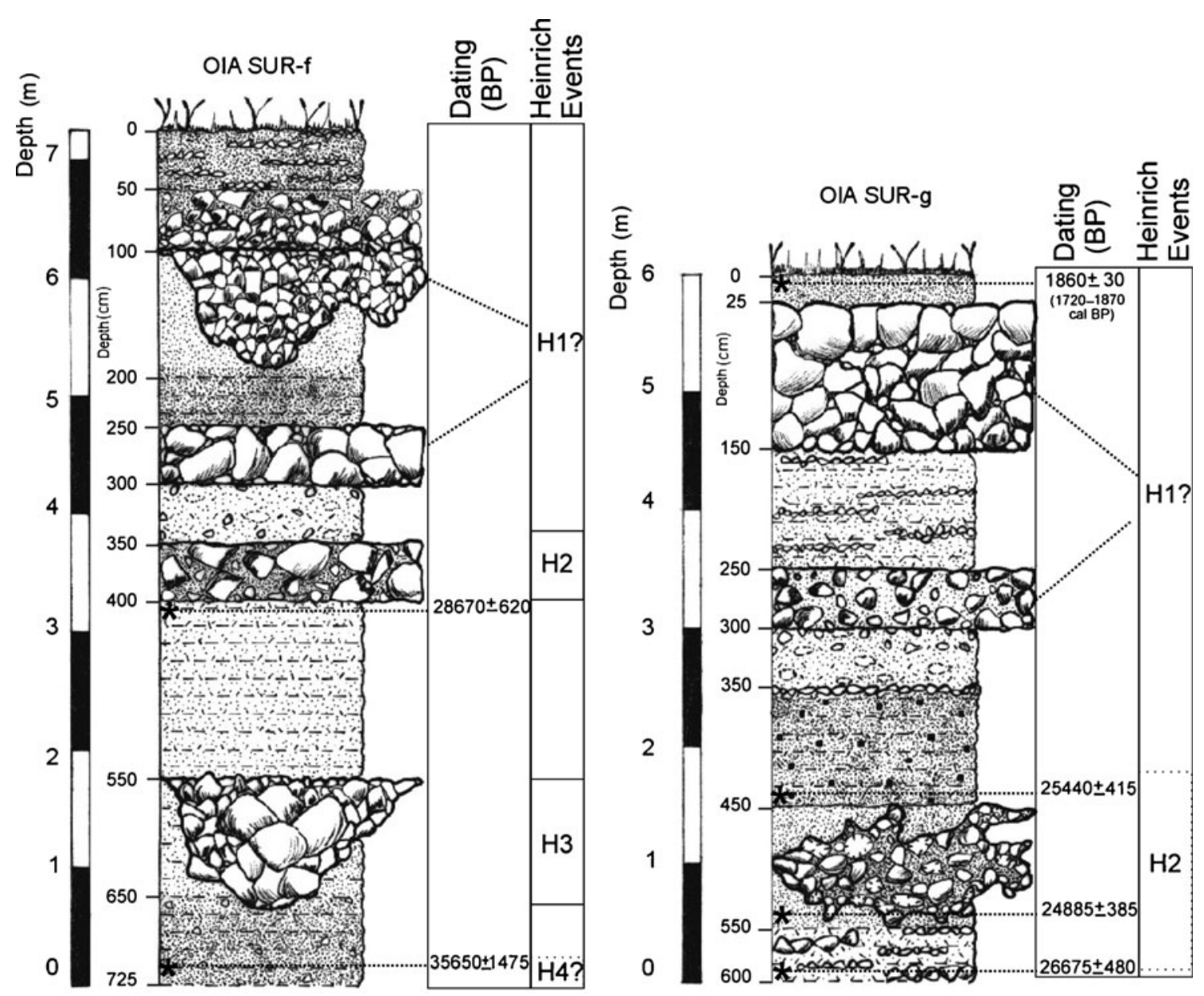

Fig. 9 Chronological context and Heinrich events in the deposit of Oia Sur ( $f$ and $g$ ) 
obtained a slightly higher value than San Xián (32 and 31 respectively). These values were obtained by adding all the points assigned for each value, as listed in Table 2. With regard to the criteria for the evaluation of the degree of vulnerability for these sites, Oia Sur scored 16, whilst San Xián scored 13. The score obtained for the "IS" (Scientific Interest) was lower for Oia (215) than for San Xián (235). However, the " $\mathrm{I}_{\mathrm{E}}$ " (Educational Interest) and " $\mathrm{I}_{\mathrm{T}}$ " (Tourist Interest) scores were almost the same for both sites $\left(\mathrm{I}_{\mathrm{E}}, 185\right.$ for Oia and 195 for San Xián; $\mathrm{I}_{\mathrm{T}}, 110$ for both) (Table 2). Both sites obtained scores above 200 with regard to scientific value, the highest category. Regarding the educational interest, both sites scored at the upper limit of the 101-200 category, making them sites of average interest. For the touristic values, both sites were in the low-level category (García-Cortés and Carcavilla 2009). Vulnerability showed differing scores for the two sites (180 for Oia and 155 for San Xián) (Table 3).

Table 6 shows the evaluation of the protection priority issues for these two geosites. The score obtained for the specific figures of protection $\left(\mathrm{PP}_{\mathrm{S}}, \mathrm{PP}_{\mathrm{E}}\right.$ and $\left.\mathrm{PP}_{\mathrm{T}}\right)$ suggests that a specific protection status is necessary for each geosite interest (scientific, educational and touristic) in the medium term. Although the values obtained are similar for both sites, there are differences for the general protection priority $\left(\mathrm{PP}_{\mathrm{G}}\right)$, with Oia Sur having a higher score than San Xián (530 and 490, respectively). A value over 500, as obtained for Oia Sur, indicates that urgent protection is necessary, whereas a value of between 201 and 500, as in San Xián, indicates that protection is recommended in the medium term. Both geosites show a high degree of vulnerability, although higher for Oia Sur. One of the main objectives, in terms of a mapping programme for the POL, should therefore be to recognise the extreme vulnerability of Oia Sur. From this starting point, the relevant local authorities should document this natural heritage area. Based on this study, this knowledge/strategy should be implemented in stages, with the option of including the two sites in the list of Spain's geosites. In order to do this, it is necessary to put strategies into practice to enable the assessment of geological sites of interest with scientific, pedagogical, cultural or touristic value; that is, those geomorphological, stratigraphical and sedimentological geosites that form part of our Geological Heritage. After they have been inventoried and characterised and their degree of interest, relevance and vulnerability quantified, the next step is to work towards their geoconservation (Brilha 2005; Carcavilla et al. 2007; Henriques et al. 2011).

\section{Conclusions}

Following the recommendations of the Council of Europe for the Conservation of Geological Heritage and Areas of Special Geological Interest (Recommendation Rec (2004) 3 ), the Council of Ministers of the Council of Europe stated that Geological Heritage constitutes a natural heritage of

Table 6 Proposal for the assessment of the protection priority (PP) of the Oia Sur and San Xián geosites: final results of the values obtained for the protection priority and specific protection type

\begin{tabular}{|c|c|c|c|c|}
\hline \multicolumn{2}{|l|}{ Interest } & \multicolumn{3}{|l|}{ Symbol } \\
\hline \multicolumn{2}{|l|}{ Scientific interest } & \multicolumn{3}{|l|}{$\mathrm{I}_{\mathrm{C}}$} \\
\hline \multicolumn{2}{|l|}{ Educational interest } & \multicolumn{3}{|l|}{$\mathrm{I}_{\mathrm{D}}$} \\
\hline \multicolumn{2}{|l|}{ Tourist interest } & \multicolumn{3}{|l|}{$\mathrm{I}_{\mathrm{T}}$} \\
\hline \multicolumn{2}{|l|}{ Vulnerability } & \multicolumn{3}{|l|}{$\mathrm{V}$} \\
\hline Protection priority & Symbol & Formula & Result: Oia & Result: San Xián \\
\hline Scientific protection priority & $\mathrm{PP}_{\mathrm{C}}$ & $\mathrm{I}_{\mathrm{C}}+\mathrm{V}$ & $215+180=395$ & $235+155=390$ \\
\hline Educational protection priority & $\mathrm{PP}_{\mathrm{D}}$ & $\mathrm{I}_{\mathrm{D}}+\mathrm{V}$ & $185+180=365$ & $195+155=350$ \\
\hline Tourist protection priority & $\mathrm{PP}_{\mathrm{T}}$ & $\mathrm{I}_{\mathrm{T}}+\mathrm{V}$ & $110+180=290$ & $110+155=265$ \\
\hline Global protection priority & $\mathrm{PP}_{\mathrm{G}}$ & $\left.\left(\mathrm{I}_{\mathrm{C}}+\mathrm{I}_{\mathrm{D}}+\mathrm{I}_{\mathrm{T}}\right) / 3\right]+\mathrm{V}$ & {$[(215+185+110) / 3]+180=530$} & {$[(235+155+110) / 3]+155=490$} \\
\hline \multicolumn{2}{|l|}{ Specific protection type } & \multicolumn{3}{|l|}{ Formula } \\
\hline \multicolumn{2}{|l|}{ Unnecessary } & \multicolumn{3}{|l|}{$\mathrm{PP}_{\mathrm{C}}, \mathrm{PP}_{\mathrm{D}}, \mathrm{PP}_{\mathrm{T}}$ or $\mathrm{PP}_{\mathrm{G}} \leq 200$} \\
\hline \multicolumn{2}{|l|}{ Necessary medium-term } & \multicolumn{3}{|c|}{$\mathrm{PP}_{\mathrm{C}}, \mathrm{PP}_{\mathrm{D}}, \mathrm{PP}_{\mathrm{T}}$ or $\mathrm{PP}_{\mathrm{G}} \leq 500$} \\
\hline \multirow[t]{2}{*}{ Urgent } & & \multicolumn{3}{|c|}{$\mathrm{PP}_{\mathrm{C}}, \mathrm{PP}_{\mathrm{D}}, \mathrm{PP}_{\mathrm{T}}$ or $\mathrm{PP}_{\mathrm{G}} \geq 501$} \\
\hline & Oia & & San Xián & \\
\hline Specific protection type, $\mathrm{PP}_{\mathrm{C}}$ & 395 & Necessary medium-term & 390 & Necessary medium-term \\
\hline Specific protection type, $\mathrm{PP}_{\mathrm{D}}$ & 365 & Necessary medium-term & 350 & Necessary medium-term \\
\hline Specific protection type, $\mathrm{PP}_{\mathrm{T}}$ & 290 & Necessary medium-term & 265 & Necessary medium-term \\
\hline Specific protection type, $\mathrm{PP}_{\mathrm{G}}$ & 530 & Urgent & 490 & Necessary medium-term \\
\hline
\end{tabular}


intrinsic scientific, cultural, aesthetic, scenic and economic interest, which must be preserved for future generations. It also highlighted the importance of the role played by geological and geomorphological conservation in many European landscapes. It is essential that the conservation and management of our geological heritage be integrated in the objectives and programmes (development and planning policies) of our governments so that areas possessing geological interest are not harmed or completely lost.

The geosites of the Southern Coast of Galicia studied here stand out in terms of their geological value for geomorphological, stratigraphical, sedimentological, pedological and other reasons. Our study highlights the need to promote the conservation and appropriate management of these sedimentary deposits as an important part of geological heritage, with their documented values, taking into account the philosophy and practices of geoconservation. It is insufficient to only identify the geological heritage of the area; its conservation and management must also be promoted. Once it has been inventoried and characterised and its degree of interest, relevance and vulnerability has been quantified, the next step should be to take measures towards its geoconservation.

The proposal in this study is to raise awareness of the Quaternary deposits which fossilise a large part of the Southern Coast of Galicia, from a scientific point of view, and to encourage a strategy of conservation and valuing by the Administrations with the power to protect them. The geosites to be preserved have been selected following the assessment criteria put forward by García-Cortés and Carcavilla (2009), along with other scientific factors, which were the result of research carried out in this region. All of this has led to the proposal that the Southern Coast sector should be declared an area-type geosite, as it includes the geosites of Oia Sur and San Xián, and about 50 other potential geosites, among which the above-mentioned ancient sedimentary deposits have been chosen as geosites worthy of conservation.

It is essential that scientific information reaches the National, Autonomous and Local Administrations so that they can develop strategies for the conservation and management of the geological heritage, whenever natural processes allow. With scientific knowledge as a basis, it is proposed that the Quaternary sedimentary deposits should be incorporated within the framework of the POL. It will be necessary to monitor the conservation and management plans, taking tourism into account in order to ensure a sustainable use of the area. It is essential that the existing legal mechanisms be reinforced and other more specific ones developed that make reference to the fact that ancient sedimentary deposits are of great geological interest. They are environmental archives of the past and therefore contain scientific information that is of great assistance in attempting to understand the evolution of the Galician coast. Informative and educational programmes should be carried out and supported, with the aim of promoting the actions necessary in the area of scientific dissemination and conservation. Finally, it should be emphasised that this area is unique on a national level due to the scientific and educational value offered by these rocks and landforms. Therefore, we would recommend to IGME the integration of these geosites in the general list of geosites for the Spanish State.

Acknowledgements Manuela Costa-Casais is supported by the Research Programme "Isidro Parga Pondal 2007"-Xunta Galicia. This research was partially funded by Project 09SEC015606PR (20092012) "Xeoarqueoloxía e reconstrución paleoambiental. Metodoloxía aplicada a contextos arqueolóxico-culturais"-_Geoarchaeology and palaeoenvironmental reconstruction. Methodology applied to cultural and archaeological contexts"-(Consellería de Economía e IndustriaXunta de Galicia) and by Portuguese National Funds through the FCT (Fundação para a Ciência e a Tecnologia) under the project PEst-OE/CTE/UI0039/2011". This paper has been prepared in collaboration with Professor M. Isabel Caetano Alves, during post-doctoral research as "Parga Pondal" carried out by Manuela Costa-Casais at the Centre for Earth Sciences, University of Minho-Centre of Geology, University of Oporto. The authors are deeply grateful to Antonio Martínez Cortizas, the reviewers and the editor for their helpful comments and contributions to the manuscript.

\section{References}

Bard E, Rostek F, Ménot-Combes G (2004) Radiocarbon calibration beyond $20000{ }^{14} \mathrm{C}$ yr BP by means of planktonic foraminifera of the Iberian Margin. Quat Res 61(2):204-214. doi:10.1016/ j.yqres.2003.11.006

Blanco-Chao R (1999) Formas y procesos geomorfológicos diferenciados en las costas de Galicia: Morfodinámica y evolución de un sector de costa rocosa: Cabo Silleiro-A Garda (Pontevedra). PhD Dissertation. Universidade de Santiago de Compostela, Santiago de Compostela

Blanco-Chao R, Costa-Casais M (2001) Influencia de formas y depósitos antiguos en la dinámica litoral: un ejemplo de la costa sur de Pontevedra (Galicia). Actas del XVI Congreso de Geógrafos Españoles. Universidad de Oviedo, CeCodet, AGE, GEA, pp 137-140

Blanco-Chao R, Costa-Casais M, Martínez-Cortizas A, Pérez A, Vázquez M (2002) Holocene evolution in Galician coast (NW Spain): an example of paraglacial dynamics. Quat Int 93-94:149 159. doi:10.1016/S1040-6182(02)00013-7

Blanco-Chao R, Costa-Casais M, Martínez-Cortizas A, Pérez A, Trenhaile AS (2003) Evolution and inheritance of a rock coast: western Galicia, Northwestern Spain. Earth Surf Process Landforms 28:757-775. doi:10.1002/esp.496

Blanco-Chao R, Pérez A, Costa-Casais M, Valcárcel M (2006) Abrasion processes in coarse-clastic beaches linked to rocky shore platforms. J Coast Res 48:21-18

Blanco-Chao R, Feal A, Valcárcel M, Costa-Casais M, Pérez A (2009) Retrocesos en acantilados sedimentarios de la costa atlántica gallega durante los últimos 3500 años. In: Morales JA, Cantano M, Rodríguez A, Delgado I (eds) Nuevas contribuciones sobre geomorfología litoral. Univ. De Huelva, SGE, SEG55, Huelva, pp $55-58$ 
Brilha J (2005) Património geológico e geoconservação: a conservação da natureza na sua vertente geológica. Palimage, Viseu

Brosche KU (1982) Studien zu jungpleistozänen un holozänem sedimenten und fossilen böden in Küstengebiet von WestGalizien (NW-Spanien). Eiszeitalter und Gegenwart 32:63-80

Brosche KU (1983) Die geomorphologisch-bodengeographische deutung der pleistozänen sedimente und böden an der Playa de Barrañán (westl La Coruña) und bei Cangas de Foz (NordGalizien). Eiszeitalter und Gegenwart 33:95-117

Browne M (2010) Geodiversity and the role of the planning system in Scotland. Engaging with geodiversity-why it matters. Conference abstracts, Edinburgh, Royal Scottish Geographical Society, Scottish Natural Heritage, British Geological Survey, and the British Society of Soil Science 6. http://www.bgs.ac.uk/research/highlights/ documents/geodiversityConference.pdf. Accessed 1 November 2011

Butzer KW (1967) Geomorphology and stratigraphy of the Paleolithic Site os Budiño (Pontevedra, Spain). Eiszeitalter und Gegenwart 33:95-117

Cairnes L (2003) Protecting Natural Heritage. Using the Australian Natural Heritage Charter, 2nd edn. Australian Heritage Commission, in association with the Australian Committee for IUCN, Canberra. http://www.ahc.gov.au/publicationass/anhc. Accessed 12 November 2010

Cano J, Fumanal MP, Ferrer C, Usera J, Blázquez AM, Olmo J (1997) Evolución de la costa meridional de Galicia durante el Cuaternario superior. Cuaternario Ibérico, Huelva, pp 33-46

Carcavilla L, López J, Durán JJ (2007) Patrimonio geológico y geodiversidad: investigación, conservación, gestión y relación con los espacios naturales protegidos. Serie Cuadernos del Museo Geominero, 7. Instituto Geológico y Minero de España, Madrid

Carcavilla L, Durán JJ, López-Martínez J (2008) Geodiversidad: concepto y relación con el patrimonio geológico. VII Congreso Geológico de España, Las Palmas de Gran Canaria. Geo-Temas 10:1299-1303

Carcavilla L, Delvene G, Díaz-Martínez E, García A, Lozano G, Rábano I, Sánchez A, Vegas J (2011) Geodiversidad y Patrimonio Geológico. Madrid NIPO: 474-11-012-3. 1st edn

Commonwealth of Australia (2004) Natural Heritage Trust Annual Report 2002-2003. An agency of the Department of the Environment and Heritage. Australian Natural Heritage Chart. http:// www.nht.gov.au/publications/annual-reports/2002-03/index.html. Accessed 12 November 2010

Costa-Casais M (2001) Análise sedimentaria e reconstrución paleoambiental da Costa Atlántica de Galicia. PhD Dissertation. Universidade de Santiago de Compostela, Servizo de Publicacións e Intercambio Científico. Santiago de Compostela

Costa-Casais M (2002) Análise sedimentaria e reconstrución paleoambiental da Costa Atlántica de Galicia. Xeográfica. Revista de Xeografía, Territorio e Medio Ambiente. Riscos Territoriais 2:191-194

Costa-Casais M, Martínez-Cortizas A, Pérez A (1994) Caracterización de un depósito costero de la Ría de Muros-Noia (La Coruña, Galicia). In: Arnáez-Vadillo J, García-Ruiz JM, Gómez-Villar A (eds) Geomorfología en España. Sociedad Española de Geomorfologia, Logroño, pp 357-368

Costa-Casais M, Martínez-Cortizas A, Pérez A (1996a) Tipos de depósitos costeiros antiguos entre o Cabo de Fisterra e o de Corrubedo. In: Pérez A, Martini P, Chesworth W, MartínezCortizas A (eds) Dinámica y Evolución de Medio Cuaternarios. Xunta de Galicia, Santiago de Compostela, pp 417-430

Costa-Casais M, Moares C, Martínez-Cortizas A (1996b) Caracterización físico-química do depósito litoral de Mougás (Pontevedra): implicaciones morfoxenéticas. In: Pérez A, Martini P, Chesworth W, Martínez-Cortizas A (eds) Dinámica y
Evolución de Medio Cuaternarios. Xunta de Galicia, Santiago de Compostela, pp 430-440

Costa-Casais M, Pérez A, Blanco-Chao R (2002) Depósitos coluviales de origen nival en la costa sur de Pontevedra (Galicia): facies y procesos deposicionales. In: Serrano E, García de Celis A, Guerra JC, Morales CG, Ortega MT (eds) Estudios recientes (2000-2002) en Geomorfología: Patrimonio, Montaña y Dinámica Territorial. Sociedad Española de Geomorfologia, Valladolid, pp 539-546

Costa-Casais M, Blanco-Chao R, Martínez-Cortizas A, Pérez A (2005) Factores determinantes en la sedimentación de los depósitos antiguos en la costa occidental de Galicia. In: Blanco Chao R, López Bedoya J, Pérez Alberti A (eds) Procesos geomorfologógicos y evolución costera. Servizo de Publicacións da Universidade de Santiago de Compostela, Santiago de Compostela, pp 295-305

Costa-Casais M, Blanco Chao R, Martínez Cortizas A, Pérez A (2007a) Evidencias de eventos Heinrich en sedimentos continentales de la costa Atlántica de Galicia (NW de la Península Ibérica). In: Pujol L, Fornós JJ (eds) Investigaciones recientes (2005-2007) en Geomorfología Litoral. Universitat de les Illes Balears, Institut Mediterrani d'Estudis Avançats, IMEDEA (CSIC-UIB), Societat d'Història Natural de les Balears. Sociedad Española de Geomorfologia, Palma de Mallorca, pp 167-173

Costa-Casais M, Blanco-Chao R, Martínez-Cortizas A, Pérez A (20072008) Los episodios Heinrich en la costa de Galicia (NW de la Península Ibérica). Un análisis a través de los sedimentos continentales. Servicio de Publicaciones, Universitat de les Illes Balears, Revista Territoris 7:39-53

Costa-Casais M, Martínez-Cortizas A, Kaal J, Ferro-Vázquez C, Criado-Boado C (2008) Depósitos coluviales holocenos del NO peninsular: geoarchivos para la reconstrucción de la dinámica geomorfológica. In: Benavente J, Gracia FJ (eds) Trabajos de Geomorfología en España 2006-2008. Sociedad Española de Geomorfologia, Cádiz, pp 83-86

Costa-Casais M, Martínez-Cortizas A, Pontevedra-Pombal X, CriadoBoado F (2009) Analysis of landforms in geoarchaeology: Campo Lameiro, NW Iberian Peninsula. Mem Descr Carta Geol d'It 87:39-51

Duplessy JC, Delibirias G, Turon JL, Pujol C, Duprat J (1981) Deglacial warming of the northeastern Atlantic Ocean: correlation with the paleoclimatic evolution of the European continent. Palaeogeogr Palaeoclimatol Palaeoecol 35:121-144. doi:10.1016/0031-0182(81)90096-1

FAO (2006) A framework for international classification, correlation and communications. World reference base for soil resources. Food and Agriculture Organization of the United Nations, Rome

Francou B, Hétu B (1989) Eboulis et autres formations de pente heterometriques. Contribution a une terminologie geomorphologique. Association Francaise du Periglaciaire, Notes et Comptes-Rendus du Groupe Régionalisation du Périglaciaire, XIV:11-69

Franz H (1967) Beiträge zur kenntnis der Beodenentwickicklung in NW-Spanien auf fossilier boden. Anal Edaf Agrobiol 26:33-51

García-Cortés A, Carcavilla L (2009) (Coords) Documento metodológico para la elaboración del inventario español de lugares de interés geológico (IELIG). Instituto Geológico y Minero de España (IGME). http://www.igme.es/internet/ patrimonio/novedades/METODOLOGIA/IELIG/V12.pdf. Accessed 1 February 2010

Gray M (2004) Geodiversity. Valuing and conserving abiotic nature. John Wiley \& Sons, West Sussex 
Guillén-Mondéjar F, Del Ramo A (2004) Patrimonio geológico y geodiversidad de la. Molata de Charán (Moratalla, Murcia) GeoTemas 6(4):103-106

Guillén-Mondéjar F (2007) La ciencia de la geología y el Patrimonio geológico en España: cultura social y ordenación del territorio. In: Restrepo C, Mata JM (eds) Actas del I Congreso Internacional sobre Geología y Minería en la Ordenación del Territorio y en el Desarrollo. Utrillas (Teruel), Universidad Politécnica de Cataluña, Dpto. de Ingeniería Minera y Recursos Naturales, pp 15-37

Hansom J, Rennie A (2010) Coastal processes, management and ecosystem services in a changing climate. Engaging with geodiversity-why it matters. Conference abstracts, Edinburgh, Royal Scottish Geographical Society, Scottish Natural Heritage, British Geological Survey, and the British Society of Soil Science 3. http://www.bgs.ac.uk/research/highlights/documents/ geodiversityConference.pdf. Accessed 1 November 2011

Heinrich H (1988) Origin and consequences of cyclic ice rafting in the northeast Atlantic Ocean during the past 130000 years. Quat Res 29:142-152. doi:10.1016/0033-5894(88)90057-9

Henriques MH, Pena dos Reis R, Brilha J, Mota T (2011) Geoconservation as an Emerging Geoscience. Geoheritage 3:117-128. doi:10.1007/s12371-011-0039-8

Kaal J, Costa-Casais M, Ferro-Vázquez C, Pontevedra-Pombal X, Martínez-Cortizas A (2008a) Soil formation of "Atlantic Rankers" from NW Spanish - a high resolution aluminium and iron fractionation study. Pedosphere 18(4):441-453. doi:10.1016/ S1002-0160(08)60035-1

Kaal J, Martínez-Cortizas A, Eckmeier E, Costa-Casais M, SantosEstévez M, Criado-Boado (2008b) Holocene fire history of black colluvial soils revealed by pyrolisis-GC/MS: a case study from Campo Lameiro (NW Spain). J Archaeol Sci 35:2133-2143. doi:10.1016/j.jas.2008.01.013

Kovda IW, Lynn W, Williams D, Chichagova O (2001) Radiocarbon age of Vertisols and its interpretation using darta on gilgai complex in the north Caucasus. Radiocarbon 3:603609

Kozlowski S (2004) The concept and scope of geodiversity. Przeglad Geologiczny 52(8/2):833-8337

Martínez-Cortizas A, Moares C (1995) Edafología y arqueología. Estudio de yacimientos arqueológicos al aire libre en Galicia. Xunta de Galicia, Santiago de Compostela

Martínez-Cortizas A, Costa-Casais M (1997) Indicios de variaciones del nivel del mar en la ría de Vigo durante los últimos 3000 años. Gallaecia 16:23-47

Martínez-Cortizas A, Costa-Casais M, Moares C (1996) Niveles dunares pleistocenos y holocenos en la costa de Galicia: hipótesis cronológica en base a su grado de edafización. In: Pérez A, Martini P, Chesworth W, Martínez-Cortizas A (eds) Dinámica y Evolución de Medio Cuaternarios. Xunta de Galicia, Santiago de Compostela, pp 391-404

Martínez-Cortizas A, Otero XL, Costa-Casais M (1997) Edafogénesis cuaternaria del depósito dunar de Figueiras (Islas Cíes-NW España): implicaciones paleoambientales. NACC: Nova Acta Científica Compostelana. Bioloxía, Servicio de Publicacions da Universidade de Santiago de Compostela 7:121-135

Martínez-Cortizas A, Costa-Casais M, López-Sáez JA (2009) Environmental change in NW Iberia between 7000 and $500 \mathrm{cal}$ BC. Quat Int 200:77-89. doi:10.1016/j.quaint.2008.07.012

Munsell Soil Color Charts (1990) Munsell Color. Macbeth Div. of Kollmorgen Instruments, Baltimore, MD, USA

Nieto LM (2001) Geodiversidad: propuesta de una definición integradora. Boletín Geológico y Minero 112(2):3-11
Nonn H (1966) Les régions cotières de la Galice (Espagne). Ètude géomorphologique. Publications de la Faculté des Lettres de L'Université de Strasbourg, Paris

Pérez A, Costa-Casais M, Blanco-Chao R (1998) L'importance des processus d'origine froide sur la cote atlantique de la Galice (Nord-Ouest de la Peninsule Iberique). Environnements periglaciaires. Association Francaise du Periglaciaire, Notes et Comptes-Rendus du Groupe Régionalisation du Périglaciaire, Université de Paris 5-XXIII:21-32

Pérez A, Costa-Casais M, Martínez-Cortizas A (1999) Nuevas aportaciones al conocimiento del cuaternario reciente en la costa atlántica de Galicia. In: Universitat de València, Departament de Geografia (ed) Geoarqueologia i Quaternari litoral. Memorial Maria Pilar Fumanal. Universitat de València, València, pp 381-390

Pessenda LCR, Gouveia SEM, Aravena R (2001) Radiocarbon dating of total soil organic matter and its comparison with $14 \mathrm{C}$ ages of fossil charcoal. Radiocarbon 43:595-601

Reimer PJ, Baillie MGL, Bard E, Bayliss A, Beck JW, Blackwell PG, Bronk Ramsey C, Buck CE, Burr GS, Edwards RL, Friedrich M, Grootes PM, Guilderson TP, Hajdas I, Heaton TJ, Hogg AG, Hughen KA, Kaiser KF, Kromer B, McCormac FG, Manning SW, Reimer RW, Richards DA, Southon JR, Talamo S, Turney CSM, van der Plicht J, Weyhenmeyer CE (2009) IntCal09 and Marine09 radiocarbon age calibration curves, 0-50000 years cal BP. Radiocarbon 51:1111-1150

Rojas J (2005) Los desafíos del estudio de la geodiversidad. Revista Geográfica Venezolana 46(1):143-152

Saa P (1986) Contribución a la cronología de sedimentos costeiros por análisis polínico. PhD Dissertation, Universidad de Santiago de Compostela, Santiago de Compostela

Serrano E, Ruíz-Flaño P (2007) Geodiversidad: concepto, evaluación y aplicación territorial. El caso de Tiermes Caracena (Soria). Boletín de la Asociación de Geografos Españoles 45:79-98

Stuiver M, Reimer P (1993) Extended ${ }^{14} \mathrm{C}$ database and revised CALIB radiocarbon calibration program. Radiocarbon 35:215230

Threnhaile AS, Pérez A, Martínez A, Costa-Casais M, Blanco R (1999) Rock coast inheritance: an example from Galicia, Northwestern Spain. Earth Surf Process Landf 24:605-621. doi:10.1002/(SICI)1096-9837(199907)24:7<605::AIDESP977>3.0.CO;2-1

Valcárcel M, Costa-Casais M (2011) Modelos paleocriológicos confrontados con depósitos costeros en el NW de la Península Ibérica. In: Ana Constante VTy (ed) Cuaternario en España y áreas afines, Avances en 2011. Resúmenes XIII Reunión Nacional de Cuaternario, Andorra, pp 31-35

Valcárcel M, Costa-Casais M, Blanco-Chao R, Martínez-Cortizas A (2011) Modelos de evolución glaciar versus depósitos costeros en el NW de la Península Ibérica: Reconstrucción paleoambiental para el Pleistoceno Final. In: Valcárcel M, Carrera P (eds) Criosferas, Suelos Congelados y Cambio Climático. III Congreso Ibérico de la International Permafrost Association (IPA), Piornedo, Lugo, España, pp 67-71

Van Vliet-Lanoë B (1988) Le rôle de la glace de ségrégation dans les formations superficielles de L'Europe de L'Ouest. Processus et héritages. Thèse d'Etat. Paris I,-Sorbonne. Publication Editec. Caen

Van Vliet-Lanoë B (1990a) Le pédocomplexe de Warneton: où en eston? Bilan paléopédologique et micromorphologique Bulletin de L'Association Française por l' Étude du Quaternaire. Quaternaire $1: 65-76$

Van Vliet-Lanoë B (1990b) The genesis of the argillic horizon in Weichselan loess of Northwestern Europe. Quat Int 5:49-56. doi:10.1016/1040-6182(90)90024-X 
Van Vliet-Lanoë B, Valadas B (1983) A propos des formations déplacées des versants cristallins des massifs anciens: Le rôle de la glace de ségregation dans la dynamique. Bulletin de L'Association Française por l' Étude du Quaternaire. Quaternaire 4:53-160

Xunta de Galicia (2010) Plan de Ordenación do Litoral de Galicia (POL). Información mantida pola Xunta de Galicia. Servizo prestado pola Conselleria de Medio Ambiente, Territorio e Infraestruturas. http:// www.xunta.es/litoral/. Accessed 13 December 2010

\section{Legislative Documentation}

Recommendation Rec (2004)3 on conservation of the geological and areas of special geological interest. (Adopted by the Committee of Ministers on 5 May 2004 at the 883rd meeting of the Ministers' Deputies). Council of Europe, Committee of Ministers
(2007) Law 5/2007, de 3 de abril, de Red de Parques Nacionales (National Parks Network). Boletín Oficial del Estado (BOE) 81, $4 / 4 / 2007$

(2007) Law 6/2007 del 11 de maio, de medidas urgentes en materia de ordenación del territorio y del litoral de Galicia. Boletín Oficial del Estado (BOE) 137, 08/06/2007

(2007) Law 42/2007, de 13 de diciembre, del Patrimonio Natural y de la Biodiversidad (Natural Heritage and Biodiversity) LPNB, Boletín Oficial del Estado (BOE) 299, 14/12/ 2007

(2007) Law 45/2007, de 13 de diciembre, de Desarrollo Sostenible del Medio Rural (LDSMR) (Sustainable Development of Rural Environment). Boletín Oficial del Estado (BOE) 299, 14/12/2007

(2011) Decree Law 20/2011, de 10 de febrero, por el que se aprueba definitivamente el Plan de Ordenación del Litoral de Galicia. Diario Oficial de Galicia (DOGA), 23/02/2011 